\title{
A synopsis of the genus Smythea (Rhamnaceae)
}

\author{
Daniel Cahen ${ }^{1,2}$ \& Timothy M. A. Utteridge ${ }^{2}$ (D)
}

Summary. A synoptic revision of the genus Smythea Seem. (Rhamnaceae) based on morphological evidence is presented. A total of 11 species are recognised; five new species are described: Smythea batanensis, S. beccarii, S. hirtella, S. poilanei and S. poomae, six new synonyms are established and a new combination is made: S. oblongifolia. Several new distribution records are reported, including $S$. macrocarpa for Borneo and Sumatra and S. oblongifolia for India. Generic delimitation between Smythea and the closely related genus Ventilago is clarified, and useful characters to identify the genera are discussed and illustrated. Distribution maps are given for each species, as well as a preliminary conservation assessment based on IUCN guidelines.

Key Words. conservation, IUCN, Malesia, South-East Asia, systematics, taxonomy, tropical climbers, Ventilagineae, Ventilago.

\section{Introduction}

Smythea Seem. is a genus of 11 species of mostly SouthEast Asian tropical climbers. The genus was placed in tribe Ventilagineae of Rhamnaceae by Hooker (1862) and retained there after phylogenetic analysis of plastid genome $r b c L$ and $t m L-F$ sequences by Richardson et al. (2000) where the tribe is monophyletic with strong support according to the strict consensus trees obtained. Smythea is closely related to Ventilago Gaertn., another group of Old World tropical climbers and the only other genus in Ventilagineae. As noted by Richardson et al. (loc. cit.), Ventilagineae are unique in Rhamnaceae in their fruits having a pronounced apical appendage. South-East Asian Rhamnaceae are represented by about 15 genera and some 100 or more species (Medan \& Schirarend 2004), many of which, including those in Ventilagineae, are poorly known and have not been included in recent taxonomic studies: the family has yet to be treated for the Flora Malesiana, or recent regional Floras such as the Flora of Peninsular Malaysia (and climbing groups were not treated in the Tree Flora of Malaya).

The genus Smythea, named in honour of William James Smythe (1816 - 1887), general and colonel-commandant of the Royal Artillery, first appeared in a list of plants collected by Berthold Seemann in the Fiji Islands (Seemann 1861). The following year Asa Gray (1862) published 'Remarks' about the plants collected by Seemann, noting that S. pacifica Seem. was similar to Ventilago bombaiensis Dalzell (= S. bombaiensis (Dalzell) S. P. Banerjee \& P. K. Mukh.) in its axillary flowers and V. lanceata Tul. (= S. lanceata (Tul.) Summerh.) in its fruit. The following month, Seemann (1862) validly published the genus, which contained only $S$. pacifica $(=S$. lanceata), a mostly coastal species with a wide distribution, whose fruit may float in seawater for months (Guppy 1906: 529; Ridley 1930: 267). Revisions at a regional scale have since been published in local Floras, e.g., King (1896) and Ridley (1922) reviewed the genus for the Malay Peninsula and Banerjee \& Mukherjee (1970) for India.

The number of species included in the genus has varied depending on the interpretation of several morphological characters at both the species and genus level. For example, in his monographic studies of Rhamnaceae in Die Natürlichen Pflanzenfamilien, Weberbauer (1895) used the fruit's undifferentiated lower portion of Smythea species in contrast to the conspicuously globose seed chamber in Ventilago as a diagnostic character. In the second edition of the Pflanzenfamilien, Suessenguth (1953) retained Weberbauer's character and enumerated six distinct species of Smythea. Using the characters described in Die Natürlichen Pflanzenfamilien, Banerjee \& Mukherjee (1969, 1970) transferred two species from Ventilago to Smythea. We discuss the utility of these fruit characters in regard to generic limits, as well as taxonomically useful characters for species delimitation, in more detail below. Using these characters a new combination is made here, $S$. oblongifolia, and five new Smythea species have been found in the herbarium material examined, and are described here.

\section{Material and methods}

Herbarium specimens from A, BKF, E, GH, K, KEP and $\mathrm{L}$ were used for study and measurements;

Accepted for publication 20 September 2017. Published online 23 December 2017

1 Life Sciences Faculty, Université de Strasbourg, 28 rue Goethe, 67083, Strasbourg, France.

2 Herbarium, Royal Botanic Gardens, Kew, Richmond, Surrey, TW9 3AE, UK. e-mail: t.utteridge@kew.org 
digital records were studied from BM, CAL, NY, P, UC, US and WRSL; an exclamation mark (!) is used to show that a specimen has been seen. Additional specimens seen are cited, but where a taxon is known only from the type, the specimen information is not repeated; barcodes are given for type information where there could be confusion with two or more sheets present in the same institution. An alphabetical index to all numbered collections examined is given at the end of the paper (Appendix 1). Material was examined under a Zeiss Stemi 1000 binocular microscope at magnifications of up to $\times 350$. Leaf anatomy terms used are from Hickey (1979), trichome terms from Theobald et al. (1979), domatia terms are from Wilkinson (1979), and other morphology terms follow Beentje (2010); note, full descriptions are only given for new taxa. Habitat notes are based on the Terrestrial Ecoregions of the World (Olson et al. 2001). Specimens were georeferenced using the point-radius method (Wieczorek et al. 2004), with coordinate uncertainty calculated using the Georeferencing Calculator (Wieczorek \& Wieczorek 2015). Coordinates are not given for localities when uncertainty or imprecision is too great. Conservation assessments in species accounts apply IUCN Red List categories and criteria (IUCN 2012), using GeoCat (Bachman et al. 2011) to calculate Extent Of Occurrence (EOO) and Area Of Occupancy (AOO) metrics. Protected areas were located using the World Database on Protected Areas online interface (IUCN \& UNEP-WCMC 2016).

\section{Generic delimitation in the Ventilagineae}

Generic delimitation in the Ventilagineae is based primarily on the shape of the fruit's seed chamber: conspicuously globose and clearly differentiated from the wing in Ventilago, compressed and gradually flattened into the wing (when present) in Smythea. Originally, authors had used different fruit characters for diagnosis, namely the presence or absence of a wing and dehiscence or indehiscence of the mature fruit. However, as discussed below, a wing is present in members of both Smythea and Ventilago, and more field data are required to clarify whether fruit dehiscence can be retained as an additional diagnostic character.

Seemann (1862) first described Smythea fruits as ovate-lanceolate wingless capsules, dehiscing along their medial line when mature. This observation was based, however, on the single species that Seemann used to describe the genus, S. lanceata, where the apical (distal) appendage above the (proximal) seed chamber is rarely planar and wing-like (Fig. 1A). In contrast, all other members of Smythea described since $S$. lanceata (except
S. poomae described in this revision) have fruits with a pronounced planar, wing-like apical appendage (Fig. 1B). Therefore, in order to include these species in Smythea, the fruit wing character can no longer be considered diagnostic. Instead, many authors since Seemann based their delimitation of Smythea and Ventilago, at least in part, on the distinction between a dehiscent or indehiscent mature fruit (e.g. Weberbauer 1895; King 1896; Ridley 1922; Suessenguth 1953; Banerjee \& Mukherjee 1970), and the fruits have been considered to be capsules in Smythea and samaras in Ventilago (Medan \& Schirarend 2004). However, except for $S$. lanceata, whether or not mature fruits dehisce is extremely difficult to infer using herbarium material, and none of the specimens we have examined have collection notes which describe dehiscent fruit. In addition, the apical appendage of fruits is occasionally seen partially splitting in both Smythea and Ventilago specimens (Cahen pers. obs.), and in this treatment we do not use the terms samara and capsule; more field observations are required to clarify if this is a useful diagnostic character, or even if the fruits dehisce. Fortunately, a more easily observable diagnostic fruit character was found to separate members of Smythea from Ventilago, namely the shape of the fruit's seed chamber. Weberbauer (1895), Ridley (1922), Suessenguth (1953) and Banerjee \& Mukherjee (1970) observed that Ventilago fruits have a conspicuous globose seed chamber clearly differentiated from the wing (Fig. 1D \& E), as opposed to Smythea fruits, which have a laterally compressed seed chamber graduating into the wing. This character was used by Banerjee \& Mukherjee (1969) in the transfer of S. bombaiensis and S. velutina (Ridl.) S. P. Banerjee \& P. K. Mukh. from Ventilago to Smythea and is used here as a diagnostic character for generic delimitation in the Ventilagineae (see also Cahen \& Utteridge 2017).

Further characters can help recognise the genus. Except for Smythea lanceata and S. poomae, Smythea fruits are slightly twisted near the base, which is not the case in Ventilago. The fruit base is often covered by the persistent calyx in Ventilago but is not in Smythea. Leaves are almost always asymmetrical at the base and leaf margins are at least obscurely crenate-serrate in Smythea, whereas many species in Ventilago have leaves with a symmetrical base and leaf margins are often entire; lateral pairs of secondary veins are generally fewer in Smythea than in Ventilago and domatia more common. Most Smythea species have flowers borne in fascicles in the axils of persistent leaves. In Ventilago, the fascicles are mostly arranged in leafless racemes or panicles. In addition, unlike those of Ventilago, some members of Smythea have flowers with distinctly 


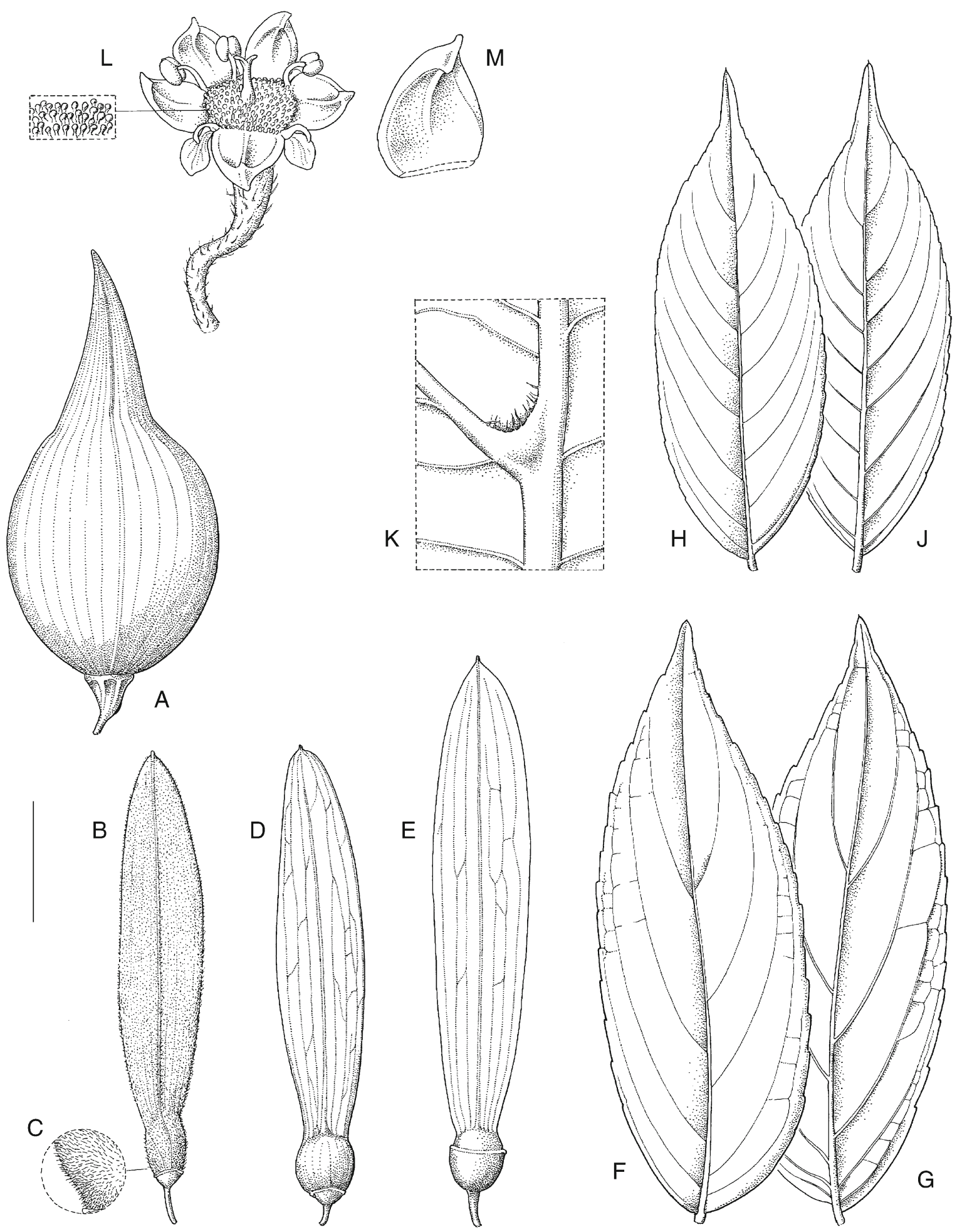

Fig. 1. Morphological characters in Smythea and Ventilago. A mature fruit of S. lanceata; B mature fruit of S. oblongifolia; C detail of hairs at the proximal part of the wing of the mature fruit of S. oblongifolia; D mature fruit of $V$. dichotoma; $E$ mature fruit of V. malaccensis; F leaf, adaxial view, S. oblongifolia; G leaf, abaxial view, S. oblongifolia; H leaf, adaxial view, S. macrocarpa; J leaf, abaxial view, S. macrocarpa; K detail of pocket domatia of S. lanceata; L flower of S. velutina; M detail of adaxial view calyx of S. velutina. Scale bars: A, B, D, E = $1.5 \mathrm{~cm} ; C=3.3 \mathrm{~mm} ; \mathrm{F}-\mathrm{J}=2 \mathrm{~cm} ; \mathrm{K}=1.2 \mathrm{~mm} ; \mathrm{L}=2.8 \mathrm{~mm} ; \mathrm{M}=1.6 \mathrm{~mm}$. A from Beccari 4062 ; B, C from Kerr 13824; D from Wiriadnata 1201; E from King's Collector [Kunstler] 7358; F, G, from Collins 1723; H, J from Spare SFN 37612; K from Lantoh SAN 68070; L, M from Gardette 1785. DRAWN BY LUCY T. SMITH. 
papillate nectary disks. Among the Ventilagineae with laterally compressed seed chambers, species which have fruit slightly twisting near the base, and papillate nectary disks, may form a genus distinct from both Ventilago and Smythea s.str. (if restricted to S. lanceata and S. poomae). Apart from the higherlevel classification of Richardson et al. (2000), no molecular phylogenetic studies have been undertaken to clarify generic limits; such studies are needed to understand if Smythea and Ventilago are distinct genera, or whether Smythea should be split in two.

\section{Key morphological characters}

\section{Leaf venation}

Many Smythea species can be recognised using leaf venation characters. Smythea leaf venation is camptodromous (sensu Hickey 1979: "secondary veins not terminating at margin”), but directed upwards and gradually diminishing apically. Secondary veins are often connected to each other by secondary vein branches, greater in size than tertiary veins, forming loops near the leaf margin and are especially distinct in S. bombaiensis and S. oblongifolia (Fig. $1 \mathrm{~F} \& \mathrm{G}$ ), for example. In all Smythea species, the two apical-most secondary veins often join each other directly. In S. batanensis however, secondary veins start joining each other directly further away from the apex, forming a series of prominent marginal loops. The number of secondary vein pairs per leaf is usually $3-5$ ( $S$. batanensis, S. beccarii, S. bombaiensis, S. lanceata), but $S$. macrocarpa Hemsl. and $S$. velutina can be recognised by the greater variability in the number of vein pairs per leaf, within a range of $3-9$ pairs (Fig. $1 \mathrm{H} \& \mathrm{~J}$ ). The angle of divergence between the secondary and primary veins, as measured on the apical side of the point of branching, is usually 35 $-55^{\circ}$ in most species, but narrower in S. oblongifolia (usually $20-35^{\circ}$ ) and wider in $S$. batanensis (usually $45-65^{\circ}$ ). Secondary veins are conspicuously prominent on the abaxial leaf surface of S. calpicarpa Kurz, S. macrocarpa, S. oblongifolia and S. velutina, and weakly to moderately prominent on the abaxial surface of all other Smythea species.

\section{Domatia}

Domatia are often found near the point of branching between primary and secondary veins on Smythea leaves. Domatia are inconspicuous when the primary vein is hairy along its length, as in S. batanensis, S. calpicarpa, S. hirtella, S. poomae and S. velutina. Pocket domatia shaped like flattened funnels are found on S. lanceata leaves (Fig. 1K), and are either glabrous or combined with tufts of hairs. All other Smythea species have domatia as tufts of hairs in vein axils, either restricted to the veins near the point of branching (S. beccarii, S. bombaiensis, $S$. macrocarpa) or both on the veins and the lamina surface (S. oblongifolia and S. poilanei).

\section{Inflorescence}

Rhamnaceae inflorescences are monotelic (Medan \& Schirarend 2004), and Smythea flowers are arranged in axillary fascicles as the result of the reduction in length of cymes. Smythea flower fascicles are described here as being either in the axils of persistent leaves or arranged in leafless racemes and panicles. The only difference between the two character states is that leaves bearing the flower fascicles in their axils are persistent in the first state and fugaceous in the second state (rather than lacking leaves from the start of growth). In $S$. hirtella and $S$. oblongifolia the inflorescences are leafless racemes or panicles, and all other members of Smythea have fascicles in axils of persistent leaves.

\section{Nectary disk papillae}

Disks of Smythea flowers are glabrous, fleshy, subpentagonal, and fill most of the hypanthium around the half-immersed ovary. Their surface is sometimes covered by distinct cylindrical projections, described here as papillae, especially the flowers of $S$. bombaiensis, S. macrocarpa, S. oblongifolia and S. velutina (Fig. 1L). Shorter papillae were observed on the disks of some flowers of S. beccarii. Disks of S. lanceata generally appear completely smooth. Often, disks are neither completely smooth nor distinctly papillose, a condition referred to here as obscurely papillose. Note: papillae are difficult to see using a $\times 10$ hand lens and are best observed using a dissecting microscope.

\section{Taxonomic treatment}

Smythea Seem. (Seemann 1862: 69). Type species: Smythea pacifica Seem. (= Smythea lanceata (Tul.) Summerh.).

Scandent shrubs or lianas, woody, without spines. Indumentum of short to long, simple, spreading to appressed, antrorse hairs, present at least at the distal end of flowering branchlets. Branchlets slender, distally flexuous. Stipules linear, fugaceous, sometimes persisting to fruiting stage. Leaves simple, alternate, distichous; base asymmetrical, rounded to cuneate; apex mucronulate; margin at least obscurely crenate-serrate, serrations tipped with callosities; secondary venation pinnate, eucamptodromous to brochidodromous, $2-9$ pairs, third order venation distinct, more or less perpendicular to primary vein; abaxial lamina surface often bearing small rounded glandular spots. Domatia common in the axils of secondary veins, tufts of hairs or pockets 
sometimes combined with tufts of hairs. Inflorescence fascicles in the axils of persistent leaves or arranged in racemes or panicles when leaves bearing fascicles are fugaceous. Flowers bisexual, 5-merous, perigynous, with a conical hypanthium; sepal lobes triangular, adaxially keeled with an apical protuberance; petals present, alternate with sepals, clawed, obcordate, each enclosing a stamen before anthesis; stamens 5, anthers dorsifixed, introrse; disk subpentagonal, filling the hypanthium, fleshy, glabrous, smooth or covered with cylindrical papillae; ovary hairy, half-immersed in disk, locules 2; style 2-fid. Fruits either crustaceous, usually inflated, even and symmetrical near the base, with no distinct wing-like apical appendage, or chartaceous to subcoriaceous, planar and not inflated, often twisted near the base and with a distinct-wing like apical appendage; apex with style remains forming a distinct mucro; persistent calyx attached at base of fruit; seed chamber 1, laterally compressed and elongated, externally indistinguishable from rest of fruit; seeds exalbuminous. $2 \mathrm{n}=24$ (S. bombaiensis).

DISTRIBUTION. Paleotropics, occurring in the Seychelles, India, South-East Asia, Melanesia and Micronesia.

\section{Key to Smythea species}

1. Fruit crustaceous, usually inflated, even and symmetrical near the base, with no distinct wing-like apical appendage and either [narrow-] ovate with apex attenuate to acuminate or narrow-ovate with apex rounded.............................2

Fruit chartaceous to subcoriaceous, planar, often twisted near the base, with a distinct wing-like apical appendage, elliptic to oblong, apex rounded to acute...

2. Leaves with $3-5$ pairs of secondary veins, well-spaced along primary vein, especially with the veins midway along sometimes separated by up to a third of the total lamina length. Fruit [narrow-]ovate, apex attenuate to acuminate......

6. Smythea lanceata

Leaves with $5-7$ pairs of secondary veins, relatively close to each other along primary vein, with the veins midway along separated by c. a fifth of the total lamina length. Fruit narrow-ovate, apex rounded.

10. Smythea poomae sp. nov.

3. Flowers fascicles in axils of persistent leaves

Flower fascicles in leafless racemes or panicles........................................................................................

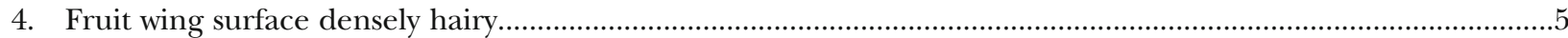

Fruit wing surface very sparsely hairy except sometimes near base...................................................................

5. Abaxial leaf surface densely hairy......

11. Smythea velutina

Abaxial leaf surface glabrous except along veins................................................................................................

6. Branchlets yellowish with majority of hairs spreading. Leaf margin sparsely hairy; secondary veins hairy, $5-7$ pairs, conspicuously prominent on the abaxial side; domatia inconspicuous.

4. Smythea calpicarpa

Branchlets fulvous with majority of hairs appressed. Leaf margin glabrous; secondary veins subglabrous, $3-5$ [-6] pairs, moderately prominent on abaxial side; domatia conspicuous..................... Smythea bombaiensis

7. Secondary veins $3-9$ pairs, close to each other along primary vein separated by $\leq 1 / 5$ of total lamina length; veins moderately to conspicuously prominent on abaxial leaf surface.

7. Smythea macrocarpa

Secondary veins $2-5$ pairs, well-spaced along primary vein, veins towards the midpoint separated by up to $\geq \frac{1}{3}$ of total lamina length; veins weakly to moderately prominent on abaxial leaf surface.

8. Leaf apex attenuate to quite long acuminate; secondary veins $2-4$ pairs; the second pair starting from the leaf base consistently much closer to the first than to the third pair; angle of divergence from primary vein usually $35-45^{\circ}$; tertiary veins spaced every c. $0.5 \mathrm{~mm}$; higher order venation reticulations indistinct..........9. Smythea poilanei sp. nov.

Leaf apex short acuminate; secondary veins $3-5$ pairs; the second pair starting from the leaf base generally about as close to the first as to the third pair; angle of divergence from primary vein usually $35-65^{\circ}$; tertiary veins spaced every c. $1 \mathrm{~mm}$; higher order venation reticulations distinct.

9. Leaf blade elliptic to wide-elliptic; margins widely crenate-serrate; abaxial lamina sparsely hairy along primary vein, domatia inconspicuous; secondary veins often joining each other directly and forming distinct loops near leaf margin...

1. Smythea batanensis sp. nov.

Leaf blade [narrow-] elliptic to narrow-ovate; margins subentire, inconspicuously crenate-serrate; abaxial lamina glabrous except for conspicuous domatia; secondary veins remaining separate near margin or indistinctly connected by secondary vein branches.

2. Smythea beccarii sp. nov.

10. Leaves with primary vein very densely hairy on abaxial side; domatia inconspicuous; petiole $2-10 \mathrm{~mm}$ long...

5. Smythea hirtella sp. nov.

Leaves with primary vein glabrous to sparsely hairy on abaxial side; domatia conspicuous; petiole $<3 \mathrm{~mm}$ long...

8. Smythea oblongifolia 
1. Smythea batanensis Cahen $\mathcal{E}$ Utteridge sp. nov. Type: Philippines, Batan Islands, Batanes, Mt Iraya [20 $28^{\prime} \mathrm{N}$ $\left.122^{\circ} 00^{\prime} \mathrm{E}\right]$, May 1930, Ramos BS 80170 (holotype K! [K000606763]; isotype K! [K000606764]).

http://www.ipni.org/urn:lsid:ipni.org:names:60475112-2

Climber [habit not recorded but inferred since all other members of Smythea are climbers]. Indumentum sparse on pedicels and at proximal end of branchlets, dense at distal end of branchlets; hairs subappresed, antrorse, fulvous. Branches slender, ascending, terete, smooth, dark reddish-brown, punctuated by small circular black glands; branchlets ridged. Stipules fugaceous, linear. Leaves: lamina elliptic to wideelliptic, $1.8-6.9 \times 1.1-3.9 \mathrm{~cm}$, chartaceoussubcoriaceous, apex attenuate to short acuminate, mucronulate, base asymmetric, rounded to broadly cuneate, margins widely crenate-serrate, obscurely near base, serrations topped by callosities; abaxial lamina sparsely hairy along primary vein; primary vein prominent abaxially; secondary veins $3-5$ pairs, weakly to moderately prominent abaxially, often joining each other directly and forming distinct loops near leaf margin, angle of divergence from primary vein usually $45-65^{\circ}$; tertiary veins slightly ascending from primary vein, spaced every c. $1 \mathrm{~mm}$; reticulations distinct on either side of lamina; lamina glabrous abaxially except along the primary vein on both sides and along the base of secondary veins; domatia inconspicuous; petiole $2-7 \mathrm{~mm}$ long, sparsely hairy. Inflorescence of fascicles in the axils of persistent leaves; flowers unknown. Fruit glabrous, except sometimes near base, colour brown, reddish-brown near base, oblong, 3.6 $6.3 \mathrm{~cm}$ long, $0.9-1.9 \mathrm{~cm}$ wide, slightly twisted near base, apex obtuse-rounded. Fig. 2.

RECOGNITION. Most similar to Smythea beccarii and S. poilanei in having 5 or fewer pairs of well-spaced secondary veins and very sparsely hairy fruit borne in the axils of persistent leaves, but differs by its inconspicuous domatia, having broader, more elliptic leaf blades, and more regularly spaced secondary veins, which often join each other directly, forming distinct loops and diverging from the primary vein at a wider angle.

DISTRIBUTION. Only known from Mount Iraya on Batan Island, Philippines. Map 1.

HABITAT. Moist broadleaf forest on stratovolcano; alt. unknown.

CONSERVATION STATUS. Data deficient (DD). IUCN Standards and Petitions Subcommittee Guidelines (2016) state that if data are so uncertain that both Critically Endangered (CR) and Least Concern (LC) are plausible categories, the DD category can be used for a taxon. The only specimen available was collected in 1930 from Batan Island's Mount Iraya and thus meets the Bla criterion for Critically Endangered (CR) status. However, Mount Iraya forests, which seem relatively well preserved on satellite imagery, are located inside an IUCN Category V (Protected Landscape/Seascape) area. In addition, lack of collections and field observations in the Batan Islands area do not allow inference of decline or fluctuation in population size or EOO and AOO.

PHENOLOGY. Collected in fruit in May. ETYMOLOGY. Named for Batan Island, the only known location where the plant has been collected.

NOTES. Three new species described here - Smythea batanensis, S. beccarii, S. poilanei - form a morphologically similar group having the flower fascicles in axils of persistent leaves, the fruit wing surface very sparsely hairy except sometimes near base, secondary veins 5 or fewer pairs, weakly to moderately prominent on the abaxial leaf surface and wellspaced along the primary vein. The spacing of the point of branching of the secondary veins from the primary vein is also useful in these taxa, especially with the secondary veins that arise approximately midway along the primary vein, spaced apart by up to more than a third of total lamina length. Smythea batanensis is recognised by its secondary veins evenly distributed along the primary vein, with an angle of divergence usually greater than $45^{\circ}$ and often directly joining each other by forming loops near the leaf margin; further diagnostic characters to identify the new species are given in the Notes to $S$. beccarii and S. poilanei.

The description is based on the study of two sheets of a single collection. Leaf characters, especially those of shape, could be variable in this species as these tend to show variability within species of Ventilagineae. However, such a wide angle of divergence of secondary veins, and the secondary veins so frequently directly joining each other by forming loops near the leaf margin was only observed for those specimens, and not found in all other collections studied, which supports the hypothesis that Smythea batanensis is a distinct species rather than representing specimens at one end of a spectrum of variation. The only other taxa of Smythea found in the Philippines are S. lanceata which has ovate fruits and $S$. oblongifolia which has flower fascicles in leafless racemes and panicles. Smythea batanensis is the only known recorded Smythea species from Batan Island.

Inflorescences of Smythea batanensis were not observed but are assumed to be borne in the axils of persistent leaves because the fruits are in persistent leaf axils. Although the two sheets of Ramos BS 80170 (K!) are marked as sheet I 


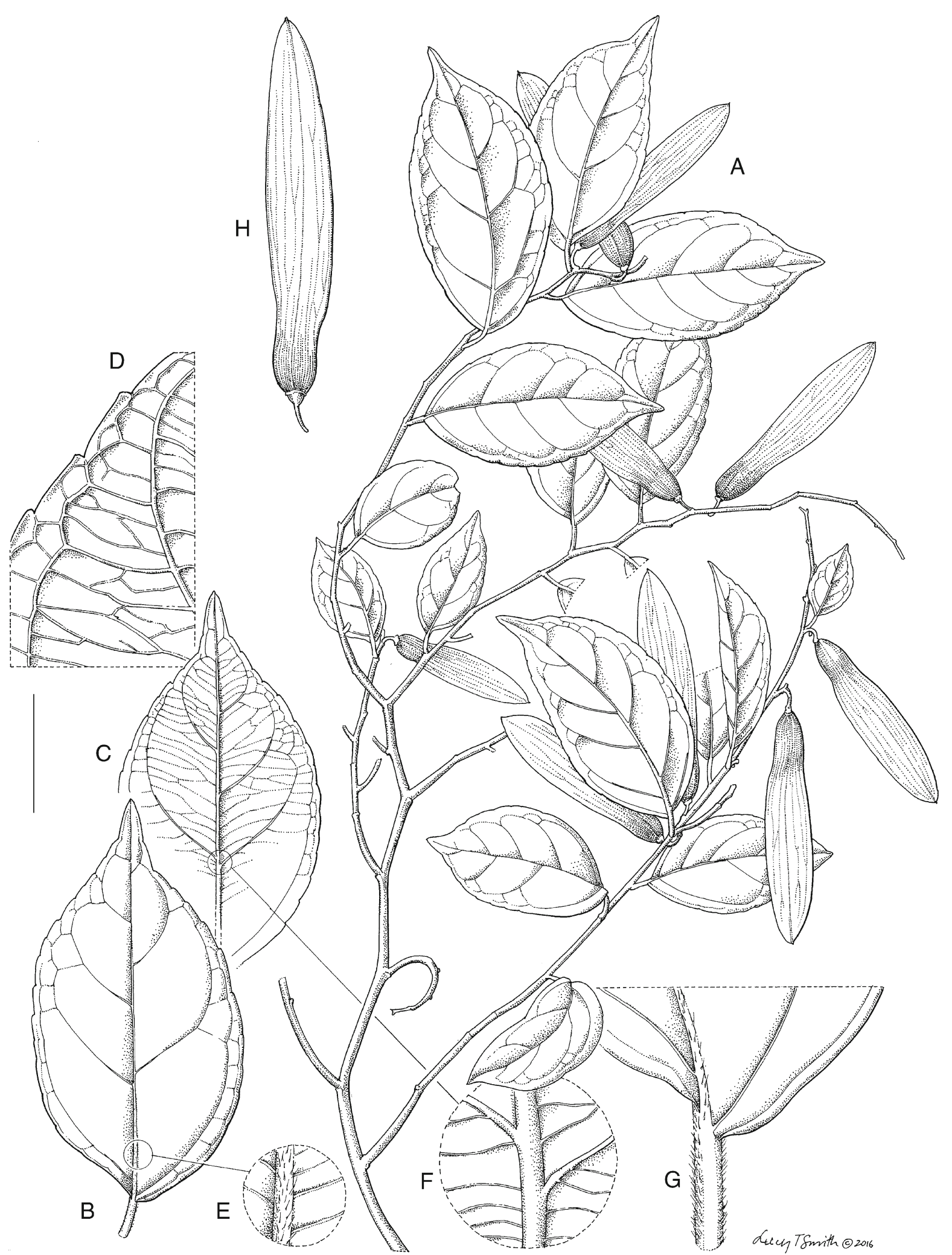

Fig. 2. Smythea batanensis. A habit; B leaf, adaxial view; C leaf, abaxial view; D detail of venation, abaxial view; E detail of abaxial midrib showing indumentum; $\mathrm{F}$ detail of adaxial midrib and secondary vein insertion showing absence of domatia; $\mathrm{G}$ petiole apex and unequal leaf base; $\mathrm{H}$ fruit. Scale bar: $\mathrm{A}=3 \mathrm{~cm} ; \mathrm{B}, \mathrm{C}=2 \mathrm{~cm} ; \mathrm{D}, \mathrm{G}=5 \mathrm{~mm} ; \mathrm{E}=7 \mathrm{~mm} ; \mathrm{F}=3.3 \mathrm{~mm} ; \mathrm{H}=1.4 \mathrm{~cm}$. All from Ramos 80170. DRAWN BY LUCY T. SMITH. 


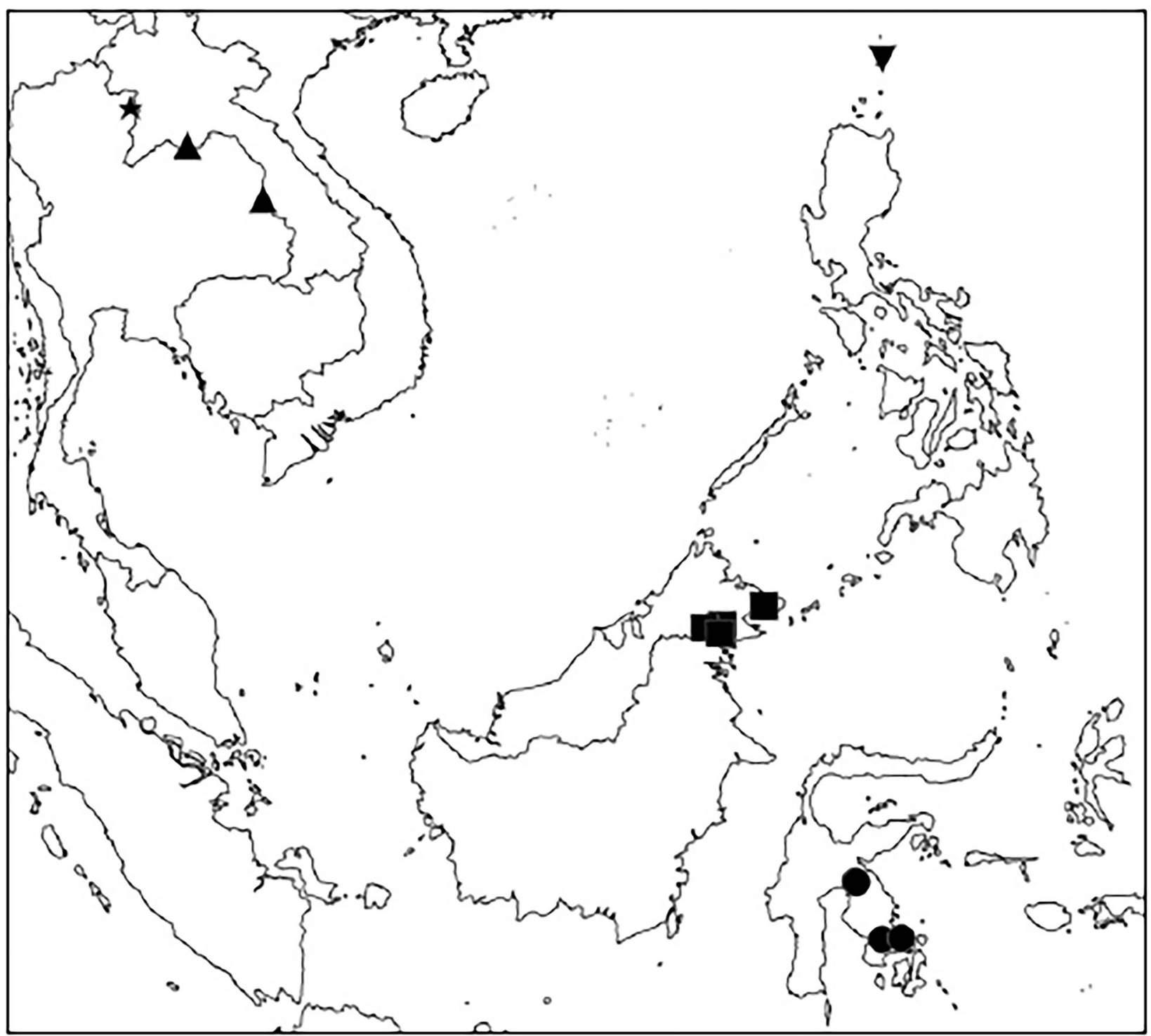

Map 1. Distribution of Smythea batanensis $(\boldsymbol{\nabla})$, S. beccarii $(\bullet)$, S. hirtella $(\boldsymbol{\bullet})$, S. poilanei $(\boldsymbol{\Delta})$ and S. poomae $(\star)$.

and sheet II, they are clearly labelled as part 1 of 2 and part 2 of 2 and are thus treated as duplicates.

2. Smythea beccarii Cahen $\mathcal{E}$ Utteridge sp. nov. Type: Indonesia, Sulawesi, Kandari [Kendari] [4 $3^{\circ} \mathrm{S}$ $\left.122^{\circ} 32^{\prime} \mathrm{E}\right], 1874$, Beccari s.n. (holotype K! [K000606778], isotypes FI, K! [K000606779]).

http:/ /www.ipni.org/urn:lsid:ipni.org:names:60475113-2

Climber to at least $12 \mathrm{~m}$. Indumentum dense at proximal part of the branchlets, all other parts very sparse; hairs appressed-antrorse. Branches terete, smooth, punctuated by small circular black glands; branchlets ridged. Stipules fugaceous, linear. Leaves: lamina [narrow-] elliptic to narrow-ovate, $3.9-8.8 \mathrm{~cm}$ long, $1.0-4.0 \mathrm{~cm}$ wide, chartaceous-subcoriaceous, apex rounded to short acuminate, mucronulate, base asymmetrical, rounded to cuneate, margins subentire, inconspicuously crenateserrate, serrations topped by callosities; lamina glabrous on both surfaces; primary vein glabrous except near secondary vein axils, prominent abaxially; secondary veins $3-5$ pairs, weakly to moderately prominent abaxially, remaining separate near margin or indistinctly connected by secondary vein branches, angle of divergence from primary vein usually 35 - 55 ; domatia conspicuous, near secondary vein axils, appearing as the abaxial lamina slightly depressed and with hairs dense on surrounding veins; tertiary veins spaced every c. 1 $\mathrm{mm}$; reticulations distinct on either side of lamina; petiole 2-8 mm long, sparsely hairy. Inflorescence fascicles in the axils of persistent leaves; pedicels with minute hairs; calyx lobes triangular, hairy abaxially; calyx lobes adaxially 


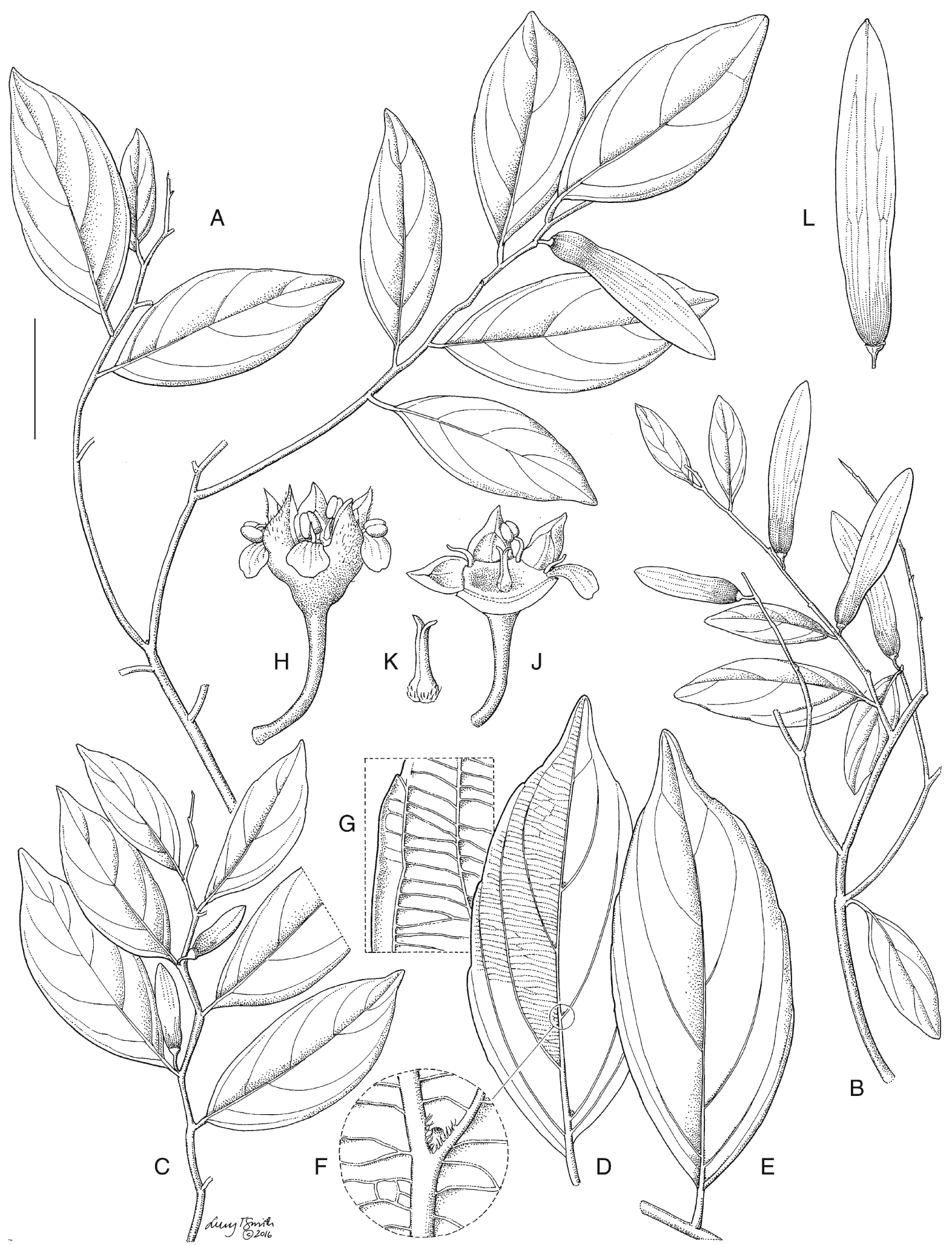

Fig. 3. Smythea beccarii. A habit with mature fruit; B detail of distal portion of branch with mature fruit showing persistent leaves; $\mathbf{C}$ detail of distal portion of branch showing immature fruit; $\mathbf{D}$ leaf, abaxial view; $\mathbf{E}$ leaf, adaxial view; $\mathbf{F}$ detail of abaxial midrib and secondary vein insertion showing domatia; $\mathbf{G}$ detail of venation, abaxial view; $\mathbf{H}$ flower, external view; J flower with two sepals removed with smooth disk; $K$ gynoecium; $L$ fruit. Scale bar: $A, B, C=3 \mathrm{~cm} ; D, E, L=2 \mathrm{~cm} ; F, G=3.3 \mathrm{~mm} ; H, J=2 \mathrm{~mm} ; K=1.3$ mm. A, B, D - G, L from Beccari s.n. (1874); C from Hennipman 5818; H - K from de Vogel 5918. DRAWN BY LUCY T. SMITH. 
keeled and with an apical protuberance; petals clawed; nectary disk subpentagonal, sometimes with very short cylindrical papillae, ovary hairy, style arms 2, short. Fruits oblong and wing-like to c. $6 \mathrm{~cm}$ long; apex obtuserounded, mucronate, wing slightly twisted near base; hairs dense, whitish, short, antrorse near the base, increasingly sparse towards apex. Fig. 3 .

RECOGNITION. Most similar to Smythea batanensis and $S$. poilanei with respect to the number of secondary veins and the very sparsely hairy fruit borne in the axils of persistent leaves; $S$. beccarii differs from $S$. batanensis in its conspicuous domatia and secondary veins remaining separate or indistinctly connected by secondary vein branches but not connecting with each other to form loops near the leaf margin; S. beccarrii differs from S. poilanei with respect to its tertiary vein reticulations that are easily seen on both sides of leaves, and its more numerous secondary veins.

DISTRIBUTION. Only known from Sulawesi Tenggara and the easternmost part of Sulawesi Selatan. Map 1. ADDITIONAL SPECIMENS EXAMINED. INDONESIA. SULAWESI: SULAWESI SELATAN, along South shore of Lake Matano [Danau Matana], W of Soroako [Saroako] [2 ${ }^{\circ} 29^{\prime} 0 " \mathrm{~S} 121^{\circ} 16^{\prime} 45^{\prime \prime E}$ ], $400 \mathrm{~m}, 14$ June 1979, Hennipman 5818 (A!, K!, KEP!, L!); S shore of Lake Mantano [Danau Matana] W of Taipa [2 $28^{\prime} 15^{\prime \prime S}$ $121^{\circ} 14^{\prime} 30$ "E], 400 m, 21 June 1979, Balgooy et al. 5918 (K!, L!); SUlaWesI TENGgARA, Opa [Rawa Aopa] Swamp, Mt Makales [4 ${ }^{\circ} \mathrm{S}^{\prime} \mathrm{S} 122^{\circ} 0^{\prime} \mathrm{E}$ ], 20 - $250 \mathrm{~m}, 16$ Nov. 1978, Prawiroatmodjo E̋ Soewoko 1769 (L!).

HABITAT. Sulawesi lowland rain forests; alt. $20-400 \mathrm{~m}$. CONSERVATION STATUS. Endangered EN B2ab(ii,iii). Smythea beccarii is only known from four collections with an AOO of $16 \mathrm{~km}^{2}$, although this is probably an underestimate. The $5720 \mathrm{~km}^{2}$ EOO would qualify the species for Vulnerable (VU) status, but this EOO is probably not a good indicator of population size given that the polygon includes areas of unsuitable habitat for the taxon, mostly cultivated land or montane rain forests, which are not putative habitats for S. beccarii. However, two of the three localities are within protected areas: Balgooy 5918 and Hennipman 5818 were collected at the edge of Danau Matano Nature Recreation Park (IUCN Category V) and Prawiroatmodjo $\mathcal{E}^{\circ}$ Soewoko 1769 within Rawa Aopa Watumohai National Park (IUCN Category II). Sulawesi still supports some lowland moist forests on steep slopes, but large areas in the south have been cleared for cultivation (Morrison 2001). Therefore, it can be inferred that, apart from within the protected areas, the species has been experiencing a steady decline in the area of its habitat.

PHENOLOGY. Collected in flower and fruit in June and Nov.
ETYMOLOGY. Smythea beccarii is named in honour of naturalist Odoardo Beccari $(1843$ - 1920) who collected the type specimen in 1874 .

NOTES. The only other taxon of Smythea recorded from Sulawesi is the widespread S. lanceata, which is found near the seashore and has ovate fruits well-suited for hydrochory. Smythea beccarii differs in having an oblong wing-shaped fruit and is found in lowland forests. When sterile, all studied specimens of both species look almost identical and their leaves are similar except that in S. lanceata the domatia are pockets, most often combined with tufts of hairs in vein axils, whereas in $S$. beccarii the domatia are only tufts of hairs in vein axils.

3. Smythea bombaiensis (Dalzell) S. P. Banerjee E $P$. K. Mukh. (Banerjee \& Mukherjee 1970: 214). Ventilago bombaiensis Dalzell (1851: 36). Type: India, Maharashtra, Chulaghat [Chorla Ghat] [15 $\left.39^{\prime} \mathrm{N} 74^{\circ} 07^{\prime} \mathrm{E}\right], 2$ Jan. 1850, Dalzell s.n. (lectotype, selected here: K! [K000681977]).

DISTRIBUTION. West India: Karnataka, Kerala, Maharashtra and Tamil Nadu. Map 2.

ADDITIONAL SPECIMENS EXAMINED. INDIA. Concan [Konkan; $18^{\circ} 5^{\prime} \mathrm{N} 73^{\circ} 25^{\prime} \mathrm{E}$ ], s.a., Stocks s.n (K!); ibid., s.a., Stocks $\mathcal{E}^{2}$ Law s.n. (L!, P!-image seen); KARNATAKA, Castle Rock [15 $\left.24^{\prime} \mathrm{N} 74^{\circ} 20^{\prime} \mathrm{E}\right], 4$ Feb. 1902, Bhide s.n. (K!); KERALA, Pamba Dam, above Kakkada R, Ranni Valley [9²3'N $77^{\circ} 10^{\prime} \mathrm{E}$ ], 13 March 1980, Ridsdale 609 (K!, L!); TAMIL NADU, "Flora of Madras", Nilgiris, Devala [11 $28^{\prime} 17^{\prime N}$ $76^{\circ} 22^{\prime} 54$ "E], Nov. 1884, Gamble 15567 (K!).

HABITAT. Lowland and montane rain forests; alt. 350 $1000 \mathrm{~m}$.

CONSERVATION STATUS. Vulnerable VU B2ab(iii). Smythea bombaiensis has an AOO of only $36 \mathrm{~km}^{2}$, below the Vulnerable threshold of 2,000 $\mathrm{km}^{2}$ (when using a $2 \mathrm{~km}$ cell size). In addition, it is known from only nine locations from 10 collections (when using literature records from Banerjee \& Mukherjee $1970^{1}$ ), several of the collections studied are over 100 years old with at least four of the collections from the $19^{\text {th }}$ century. Habitats in the west of India are under threat, for example large parts of the natural forests of the Western Ghats have been cleared and converted, while the remaining fragmented forests are threatened (Rawat et al. 2001).

PHENOLOGY. Collected in fruit and flower from Dec. to June.

NOTES. Smythea bombaiensis is recognised by having both a hairy fruit wing borne in the axils of persistent leaves and a glabrous abaxial leaf surface. The presence of conspicuous

\footnotetext{
${ }^{1}$ Matherau [Matheran; $18^{\circ} 59^{\prime} \mathrm{N} 73^{\circ} 16^{\prime} \mathrm{E}$ ], Feb. 1950, Adhatia s.n. (BLAT); Mahabaleshwar Fitzgerald Ghat $\left[17^{\circ} 56^{\prime} \mathrm{N} 73^{\circ} 39^{\prime} \mathrm{E}\right], 30$ Dec. 1943, Bole 1291 (BLAT); Khandala [18 $\left.46^{\circ} \mathrm{N} 73^{\circ} 23^{\prime} \mathrm{E}\right], 5$ March 1944, Santapau 3653 (DD); Devimana Ghat, N Kanara, [14³2'N 74³4'E], Dec. 1919, Sedgwick 6909 (CAL).
} 


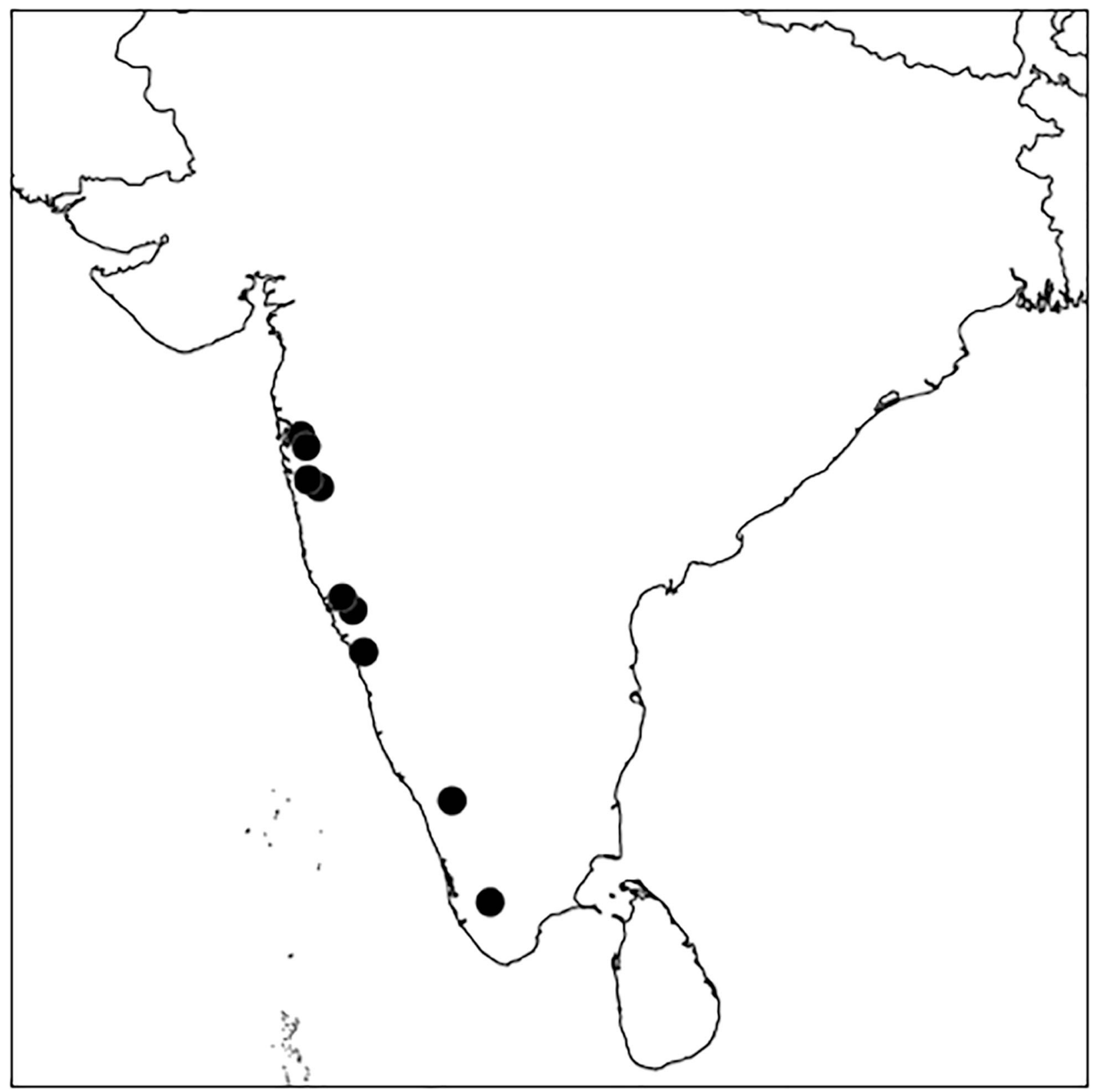

Map 2. Distribution of Smythea bombaiensis ( $\bullet$ ) (including literature citations).

domatia on the abaxial leaf surface and loops near the leaf margin formed by secondary vein branches connecting secondary veins, are additional diagnostic characters. It is the only taxon of Smythea recorded from the Western Ghats.

4. Smythea calpicarpa Kurz (1872: 301). Type: Burma, Tenasserim [Taninthayi], 1837, Helfer s.n. (lectotype, designated here: K! [K000681976], isolectotype: K! [K000606780]).

DISTRIBUTION. Known from a single collection from the Taninthayi Region of Burma.
HABITAT. Myanmar coastal rainforests.

CONSERVATION STATUS. Data deficient: DD. Burma is poorly collected, and Smythea calpicarpa is only known from a single collection of imprecise locality in 1837. However, whilst localities are not always given on his labels, this specific area was explored by Helfer, and hence we have assumed S. calpicarpa to be collected from this location. However, in this region, most of the seasonal evergreen forest has been cleared for agriculture and heavy degradation has occurred near Myeik and Dawei since 1837 (Srikosmatara et al. 2001). We need more information on the distribution of this species in Burma, and if it was only found in 
this region, then it is likely that the taxon could be critically endangered.

NOTES. Smythea calpicarpa is recognised by the absence of conspicuous domatia, the spreading yellowish hairs on its branchlets and $5-7$ pairs of abaxially conspicuously prominent, hairy secondary veins. The only other taxa of Smythea recorded in the Kra Isthmus are S. lanceata and S. oblongifolia. Smythea calpicarpa differs from both taxa in having no conspicuous domatia, from $S$. lanceata in the densely hairy branchlets and evenly spaced secondary veins, and from S. oblongifolia in having fruits in the axils of persistent leaves.

A specimen collected on South Andaman Island was identified as Smythea calpicarpa despite the presence of leafless racemes branching off (Port Mouat hill jungle, 28 Jan. 1915, King s.n. (K!)). However, in addition to leafless racemes, the presence of conspicuous domatia and of a narrow-acute angle of divergence of secondary veins, indicate that the specimen belongs to $S$. oblongifolia.

5. Smythea hirtella Cahen $\mathcal{E}$ Utteridge sp. nov. Type: Malaysia, Sabah, Lahad Datu, Tabin Wildlife Reserve, 19 June 2000, Madani et al. 145373 (holotype K! [K000271426]; isotype SAN).

http:/ /www.ipni.org/urn:lsid:ipni.org:names:60475114-2

Climber to $20 \mathrm{~m}$ long. Indumentum dense at distal end of branchlets; hairs subappressed, antrorse, fulvous. Branches slender, terete, smooth, punctuated by dark circular glands; branchlets ridged. Stipules fugaceous, occasionally persistent and seen at fruiting stage, linear, with very minute hairs. Leaves: blade narrow ovate to oblong, $1.5-$ $7.5 \mathrm{~cm}$ long, $0.8-3.1 \mathrm{~cm}$ wide, chartaceous-subcoriaceous, apex attenuate to acuminate, mucronulate, base asymmetric, rounded to cuneate, margins widely crenate-serrate, obscurely near base, serrations topped by black callosities; primary vein prominent abaxially, very densely hairy, hairs subappressed, antrorse; secondary veins $4-7$ pairs, weaklymoderately prominent abaxially, sparsely hairy, regularly spaced and remaining separate or obscurely connected by secondary vein branches, angle of divergence from primary vein usually $35-55^{\circ}$; reticulations distinct; lamina glabrous on both surfaces, without conspicuous domatia; petiole $3-10 \mathrm{~mm}$ long, very densely hairy. Inflorescence fascicles in leafless racemes with c. 10 flowers in each fascicle; bracts narrowly triangular, $0.6 \mathrm{~mm}$ long, pilose; pedicels with relatively sparse spreading hairs; calyx lobes triangular, hairy abaxially, glabrous and keeled adaxially; petals clawed, notched, hairy abaxially; nectary disk subpentagonal, weakly papillose, ovary hairy, style arms 2, short. Fruit densely hairy, dark brown, oblong, apex acute when young; mature fruit unknown. Fig. 4.
RECOGNITION. Smythea hirtella is unique in Smythea in having both a relatively long petiole (equal to c. $12 \%$ of total leaf length), and very densely hairy primary vein on the abaxial side. It is most similar to S. oblongifolia in having flower fascicles borne in leafless racemes and hairy, basally twisted fruit wings, but differs in the aforementioned characters and its glabrous abaxial lamina at secondary vein axils.

DISTRIBUTION. Endemic to Borneo, currently known only in the east of Sabah. Map 1.

ADDITIONAL SPECIMENS EXAMINED. MALAYSIA. SABAH: KINABATANGAN, Hiew Shing logged area, coupe 1979 [4³5'N 117 04'E], 26 Aug. 1982, Krispinus SAN 95986 (K!, KEP!, L!); TAWAU, Benaword [442'N 117 $33^{\circ} \mathrm{E}$ ], 23 April 1980, Fedilis $\mathcal{E}$ Sumbing SAN 91824 (K!, KEP!, L!); Geynawood logged area, mile 19, Luasong Rd. [4 $28^{\circ} \mathrm{N}$ $\left.117^{\circ} 29^{\prime} \mathrm{E}\right], 6$ Oct. 1982, Krispinus SAN 95994 (K!, L!).

HABITAT. Borneo lowland rain forests; alt. $100-500 \mathrm{~m}$. CONSERVATION STATUS. Endangered EN Blab(iii). The taxon is only known from four localities within an EOO of $3000 \mathrm{~km}^{2}$. Bornean lowland rain forests have been experiencing severe fragmentation and conversion (Loucks 2001). Only Madani et al. SAN 145373 is known to have been collected inside a protected area: Tabin Wildlife Reserve (IUCN Category IV).

PHENOLOGY. Collected in flower in April, Aug. and Oct.; collected in fruit in June.

ETYMOLOGY. The specific epithet refers to the abaxially very densely hairy primary vein and very densely hairy petiole. The diminutive suffix - ella refers to the relatively small leaves, $1.5-7.5 \mathrm{~cm}$ long and $0.8-3.1 \mathrm{~cm}$ wide.

NOTES. Neither mature flowers nor fruit were available for study, however, fruit were mature enough to observe a basally twisted oblong wing with a flattened seed chamber, indicating that Smythea hirtella is a member of the genus Smythea. The only other taxa of Smythea found in Sabah are S. lanceata, S. macrocarpa and S. oblongifolia. Smythea hirtella differs from both $S$. lanceata and $S$. macrocarpa in the flower fascicles being borne in leafless racemes, and from S. oblongifolia in the very densely hairy primary vein, in its weakly to moderately prominent secondary veins, and the absence of conspicuous domatia.

6. Smythea lanceata (Tul.) Summerh. (Summerhayes 1928: 389). Ventilago lanceata Tul. (Tulasne 1857: 121). Type: Seychelles, Mahé, s.a., Pervillé 126 (not found);

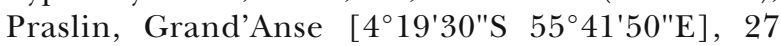
Sept. 1906, Dupont 17 (neotype, designated here: K! [K00036275]).

Ventilago cernua Tul. (Tulasne 1857: 123) synon. nov. Type: Indonesia, West Papua, Rawak [Rauki] [ $0^{\circ} 02^{\prime} \mathrm{N}$ $130^{\circ} 53^{\prime} \mathrm{E}$ ], 1817 - 1820, Gaudichaud 111 (lectotype, designated here: P!-image seen [P06831718]). 
Berchemia trichantha Miq. (Miquel 1861: 331). Smythea trichantha (Miq.) C. K. Schneid. (Schneider 1916: 218). Type: Indonesia, Pulau Sangiang, "Poeloe Sangian Str. Sunda" [557'S 10551'E], s.a., Teijsmann 2977 (lectotype, selected here: U!-image seen [U0005783]; isolectotypes GH!, K! [K000606802], L-2 sheets! [L0552450; L0552451]).

Smythea pacifica Seem. (Seeman 1861: 255). Type: Fiji, Viti Levu, June 1860, Seemann 79 (lectotype, designated here: K! [K000681971]; isolectotypes BM!-image seen [BM000838644], P!-image seen [P06886654]).

Smythea novoguineensis Scheff. (Scheffer 1876: 14). Type: Indonesia, "Découverte par M. Teysmann dans les îles Roembobo et Salawati et près de Doré [Manokwari]", Teijsmann s.n. (lectotype, selected here: U!-image seen [U1541270]).

Smythea reticulata King (1896: 381). Type: Singapore, Bajau, 10 Dec. 1892, Ridley 3592a (lectotype, selected here: K! [K000606800]; isolectotype: K! [K000606801]). Smythea dupontii Hemsl. (Hemsley 1916: 9). Type: Seychelles, Mahé, s.a., Pervillé 126 (not found); Praslin, Grand'Anse [4¹9'30"S 5541'50"E], 27 Sept. 1906, Dupont 17 (lectotype, selected here: K! [K00036275]). Ventilago fasciculiflora Merr. (Merrill 1916: 287). Type: Indonesia, Ambon, July - Nov. 1913, Robinson 1818 (lectotype, selected here: K! [K000681919]; isolectoypes: L!, NY!-image seen [NY00415081]).

DISTRIBUTION. Widely distributed along coasts from the Seychelles to the Fiji Islands, throughout South-East Asia from the Malay Peninsula to New Guinea. Map 3. ADDITIONAL SPECIMENS EXAMINED. BRUNEI. Tutong, Telisai R. [4 ${ }^{\circ} 44^{\prime} \mathrm{N} 114^{\circ} 34^{\prime} \mathrm{E}$ ], 20 June 1966, Niel 4188 (L!). FEDERATED STATES OF MICRONESIA. CAROLINE ISLANDS: Pohnpei, Nanmatol Islet, Matalanim Distr. [6 50 '25"N 158 19'54"E], 13 m, 11 Aug. 1946, Fosberg 26395 (K!, L!, P!-image seen); ibid., Matiro (Machiru) Islet [ $\left.1^{\circ} 04^{\prime} 07^{\prime \prime N} 154^{\circ} 48^{\prime} 35^{\prime \prime E}\right], 5$ Aug. 1946, Fosberg 26147 (US!-image seen); Yap, off trail to Inuf, S.E. Yap [9²9'35"N 138 05'50"E], 10 m, 22 July 1965, Cushing 460 (US!-image seen). FIJ. 1878 1879, Horne 502 (K!); VANUA LEVU: Cakaudrove, Dromoninuku, sea level, 28 April 1969, Smith 16822 (K!); Mathuata, banks of lower Lambasa R. [16 $\left.26^{\prime} \mathrm{S} 179^{\circ} 22^{\prime} \mathrm{E}\right]$, sea-level, 18 Nov. 1947, Smith 6628 (K!, P! image-seen); Labasa [16 ${ }^{\circ} 26^{\prime} \mathrm{S} 179^{\circ} 22^{\prime} \mathrm{E}$ ], 8 Nov. 1922, Greenwood 264A (K!); Macuata Coast [16 $\left.27^{\prime} \mathrm{S} 179^{\circ} 05^{\prime} \mathrm{E}\right]$, Nov. 1923, Greenwood 264A (K!); ibid., Dec. 1924, Greenwood 264C (K!)]; ibid., 26 July 1926, Greenwood 264A (K!); Lami nr Suva [18 $07^{\circ} \mathrm{S} 178^{\circ} 25^{\prime} \mathrm{E}$ ], 26 Nov. 1928, Tothill 479 (K!); Suva [18 $09^{\prime}$ S $\left.178^{\circ} 27^{\prime} \mathrm{E}\right]$, Nov. 1927, Tothill 74 (K!); ibid., 1929, Tothill 7479 (K!); VITI LEVU: 1855, Milne 289 (K!); June 1860, Seemann 79 (BM!-image seen, K!, P!-image seen); Rewa, limestone rocks near the quarry, beyond Lami village, just above the tidal marsh $\left[18^{\circ} 07^{\prime} \mathrm{S} 178^{\circ} 25^{\prime} \mathrm{E}\right], 3 \mathrm{~m}$,
6 Feb. 1928, Gillespie 4589 (K!); Sigatoka [1808'30"S 177³0'30"E], 10 Oct. 1919, Greenwood 264 (K!); WAYA: Yasawa Gr, Yalobi [17²18 $30^{\prime \prime S}$ 17707'15"E], 5 Feb. 1964, Koroivebau 13670 (K!). INDIA. ANDAMAN ISLANDS: LITTLE ANDAMAN, Dugong Creek [1046'N 92 $35^{\prime} \mathrm{E}$ ], sea level, 5 Sept. 1976, Bhargava 4408 (L!). INDONESIA. BANGKA-BELITUNG ISLANDS: Blitoeng [Pulau Belitung], s.a., van Ooststroom E L Lütjeharms 11186 (L!); ENGGANO ISLAND: Strand bij Kiojoh [5²4'40"S 102 11'40"E], 13 June 1936, Lütjeharms 4699 (A!, K!, L!); KALIMANTAN: East Kalimantan, Balikpapan, Kenangan ITCI [1 ${ }^{\circ} 16^{\prime} 30^{\prime \prime}$ 116 49'45"E], 31 May 1920, [collector unknown] TFB 1247 (L!); West Kalimantan, oever Kapoeas beneden Pontianak [0 $0^{\circ} 16^{\prime} \mathrm{S} 109^{\circ} 20 ' \mathrm{E}$ ], 1859 - 1860, de Vriese $\mathcal{E}^{\circ}$ Teijsmann s.n. (L!); KEPULAUAN SERIBU: Eiland Noordwachter, N hleft.[Pulau Sabira] [5²'14"S $106^{\circ} 27^{\prime} 41 \mathrm{\prime E}$ ], 1/2 m, 8 Sept. 1921, van Slooten E Backer 35069 (L!); MALUKU: ARU, s.a., Riedel s.n. (K!); HALMAHERA ISLAND, Dudinga [0 $50^{\circ} \mathrm{N} 127^{\circ} 40^{\prime} \mathrm{E}$ ], 3 Nov. 1951, Idjan $\mathcal{E}^{\circ}$ Mochtar 398 (A!, L!); PULAU AMBON, Hila [ $3^{\circ} 36^{\prime} \mathrm{S}$ $128^{\circ} 7$ 'E], s.a., Teijsmann s.n. (L!); PULAU BURU, Boeroe, Leksoela [Leksula] [3 $\left.{ }^{\circ} 46^{\prime} \mathrm{S} 126^{\circ} 31^{\prime} \mathrm{E}\right], \pm 500 \mathrm{~m}, 17$ Oct. 1921, Toxopeus 628 (L!); PULAU OBI, W. part, Jikodolong, $1^{\circ} 28^{\prime} \mathrm{S} 127^{\circ} 30^{\prime} \mathrm{E}, 1 \mathrm{~m}, 23$ Nov. 1974, de Vogel 4258 (K!, L!); SERAM ISLAND, O. Seram, Woeroe [324'0"S 130³9'45"E], 0 m, 6 Feb. 1918 Kornassi 979 (L!); Kamp: Ketapang Miring [3¹8'30"S 128 3'30"E], 0 m, 2 May 1918, Kornassi 1205 (L!); SULABES ISLAND, Wanaboh, s.a., Atjeh 281 (L!); TANIMBAR ISLANDS, Timor Laut, s.a., Riedel s.n. (L!); Larat, Ritabel [79'45"S 131 43'45"E], 25 March 1956, van Borssum Waalkes 3231 (K!, L!); NUSA KAMBANGAN ISLAND: 9 April 1915, Backer 21001 (K!, L!); PANAITA ISLAND: W ot Tg. Parat, easterly lagoon [6 ${ }^{\circ} 32^{\prime} 0^{\prime \prime S} 105^{\circ} 14^{\prime} 15^{\prime \prime E}$ ], 1 Oct. 1951, van Borssum Waalkes 777 (L!); SULAWESI: Takimpoe [5³2'S $122^{\circ} 51^{\prime} \mathrm{E}$ ], Oct. 1913, Rachmat 807 (L!); WEST PAPUA: KAIMANA, Kaimana [339'S 133 44 'E] 20 m, 3 June 1941, Aet 198 (L!); [ $2^{\circ} 14^{\prime} \mathrm{S} 125^{\circ} 54$ 'E] MANOKWARI, Maroeni, near Andai, SW of Manokwari [0 $0^{\circ} 58^{\prime} \mathrm{S} 134^{\circ} 0^{\prime} \mathrm{E}$ ], $10 \mathrm{~m}, 24$ May 1961, Schram BW 10623 (L!); MISOOL, Waigama [1 ${ }^{\circ} 52^{\prime} \mathrm{S} 129^{\circ} 44^{\prime} \mathrm{E}$ ], 12 Sept. 1948, Pleyte 821 (A!, K!, L!); SOUTH SORONG, Sorong. Kp. Baroe. [1 ${ }^{\circ} 50^{\prime} \mathrm{S} 132^{\circ} 15^{\prime} \mathrm{E}$ ], 27 July 1948, Djamhari 388 (L!); MALAYSIA. Nam Heng, May 1927, Teruya 360 (KEP!); PENINSULAR MALAYSIA: JOHOR, S. Sedili [1 ${ }^{\circ} 52^{\prime} 30^{\prime \prime N} 103^{\circ} 57^{\prime} 30^{\prime \prime E}$ ], 4 June 1936, Corner 31460 (K!); Sungei Tebrau, in mangrove by roadside near bridge [1 $\left.{ }^{\circ} 29^{\prime} 45^{\prime \prime} \mathrm{N} 103^{\circ} 47^{\prime} 45^{\prime \prime} \mathrm{E}\right], 13$ June 1965, Sinclair 10807 (E!, K!, L!); Sungai Tukong estate [ $1^{\circ} 27^{\prime} \mathrm{N} 103^{\circ} 56^{\prime} \mathrm{E}$ ], 22 July 1921, Spare 931; PERAK, Kelumpang Main land Res. Krian [4 $53^{\prime} 45^{\prime \prime} \mathrm{N}$ 


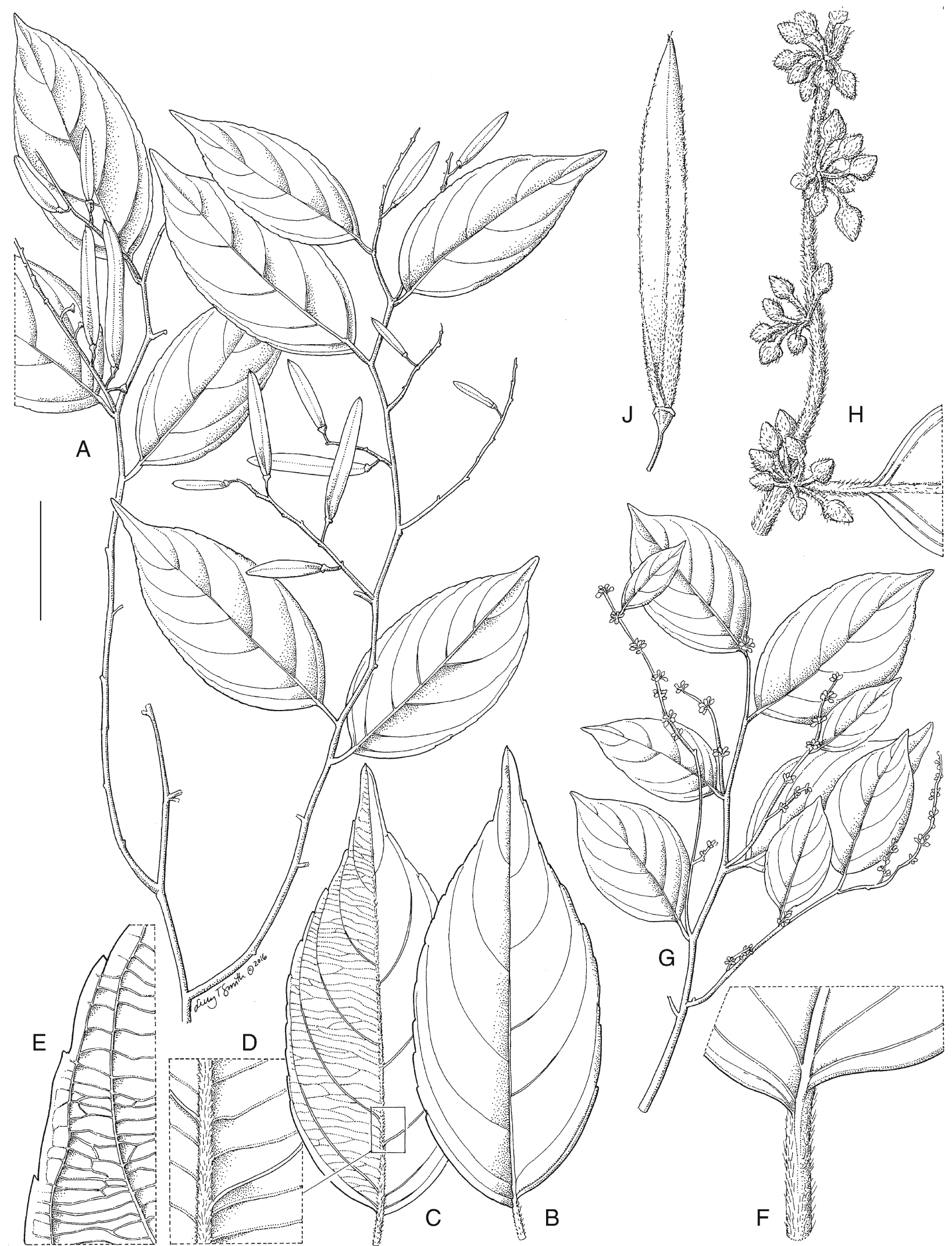

Fig. 4. Smythea hirtella. A habit with mature fruit; B leaf, adaxial view; C leaf, abaxial view; D detail of abaxial midrib and secondary vein insertion; $\mathbf{E}$ detail of venation, abaxial view; $\mathbf{F}$ distal portion of petiole and lamina base; $\mathbf{G}$ flowering habit; $\mathrm{H}$ inflorescence; $\mathbf{J}$ immature fruit. Scale bar: A, $G=3 \mathrm{~cm} ; B, C=2 \mathrm{~cm} ; D-F, H=5 \mathrm{~mm}$; J $=1 \mathrm{~cm}$. A - F, J from Madani SAN 145373; G, H from Fedilis Sumbing SAN 91824. DRAWN BY LUCY T. SMITH. 


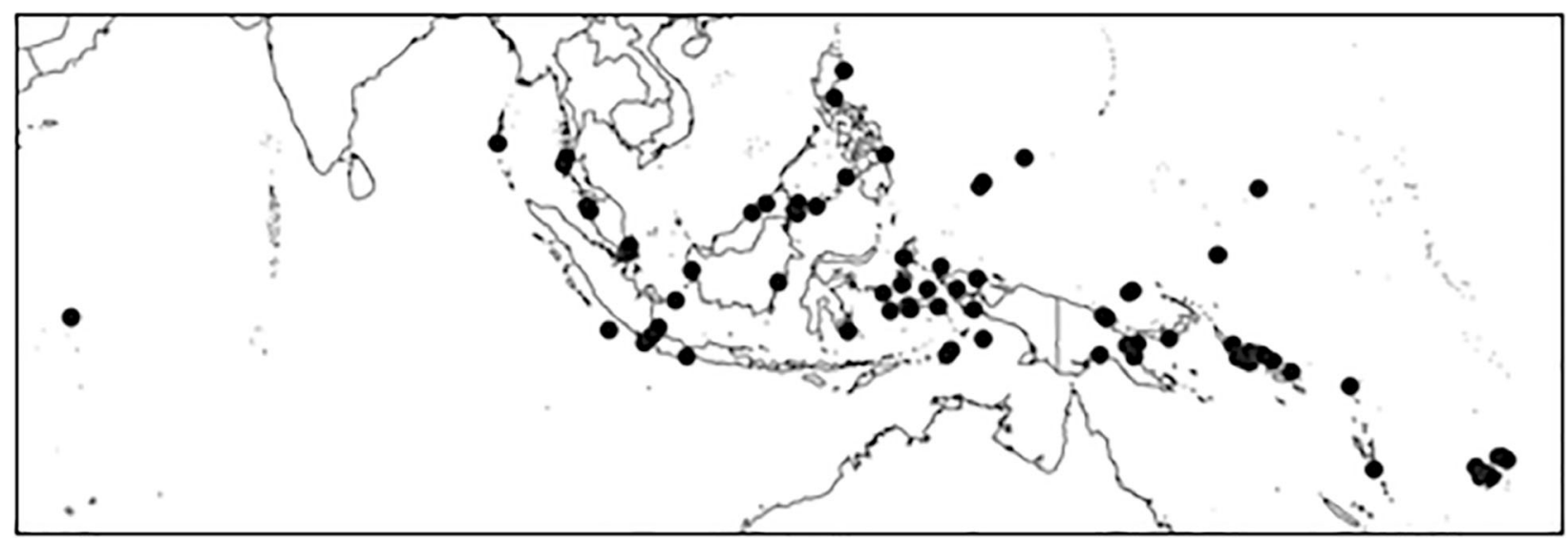

Map 3. Distribution of Smythea lanceata $(\bullet)$.

$100^{\circ} 31^{\prime} 45^{\prime E}$ ], 18 Nov. 1919, Borges 3410 (K!); Kalumpang Is. F.R. C10/13 [453'45"N 100³1'45"E], 11 July 1928, Sudin 9815 (KEP!); PINANG, Polo Jerejak [Pulau Jerejak] [5¹9'15"N 100¹9'E], June 1890, Curtis 2429 (K!, P!image seen); SABAH: KINABATANGAN, Sg. Gologop, 5 34'92"N, 118 32'86"E, 5 Sept. 2008, Ubaldus et al. SAN 149661 (KEP!); LAHAD DATU, Darvel Bay Islands, Pulau Saranga, $4^{\circ} 55^{\prime} 41^{\prime \prime N} 118^{\circ} 11^{\prime} 58^{\prime \prime E}, 16$ m, 5 Aug. 2010, Joel et al. SAN 152284 (KEP!); PULAU TIMBUN MATA [4³8'45"N 118 $27^{\circ} 15^{\prime \prime} \mathrm{E}$ ], 25 Sept. 1929, Lamtoh SAN 68070; WEST COAST, Pantai Pinping [ $5^{\circ} 30^{\prime} \mathrm{N} 115^{\circ} 466^{\prime} \mathrm{E}$ ], 27 Aug. 1988, Amin SAN 115220 (E!, K!); SARAWAK: 1865 1868, Beccari 4062 (K!, P!-image seen); PALAU. Babeldaob, Airai Munic., SW Babeldaob Id., along main road between bridge to Koror \& Gihmel R., 7²2'N 134³1'30"E, 20 m, 1 Aug. 1978, Canfield 527 (US!-image seen); Koror, Ngerbechedesau [7²0'30"N 134 29'30"E], 14 April 1969, Fisher 7 (L!); Pelew Is. [Peleliu] [700'45"N 134¹4'45"E], Aug. 1933, Kanehira 2397 (K!, P!-image seen). PAPUA NEW GUINEA. Kaiser Wilhelmsland, 15 March 1889, Hellwig 435 (K!);. s.l., s.a., Teijsmann 7759 (K!, L!); ibid., Teijsmann 779 (P!-image seen); ADMIRALTY ISLANDS: March 1875, Moseley s.n. (K!); Los Negros Island, $2^{\circ} 00^{\prime} \mathrm{S} 147^{\circ} 25^{\prime} \mathrm{E}, 5 \mathrm{ft}[0 \mathrm{~m}], 17$ June 1971, Stone $\mathcal{E}^{\circ}$ Streimann 53585 (A!, K!, L!); KIKORI: Uramu Island, Kimomeri village [7³5'S $144^{\circ} 36^{\prime} \mathrm{E}$ ], sea level, July 1955, Gray Eै Floyd 8010 (A!); MADANG: Laing Isl. [4²13'44"S 14456'34"E], 29 Dec. 1979, Demoulin E゚ Smeets 5672 (A!, K!, L!); ibid., 26 July 1979, Iserentant 9022 (P!-image seen); Hansa Bay, near Bogia, Laing Island, $4^{\circ} 10^{\prime} \mathrm{S} 144^{\circ} 52^{\prime} \mathrm{E}$, sea level, 26 May 1980, Goethebeur 3212 (L!); ibid., 10 June 1980, Goethebeur 3363 (L!); Kaiser Wilhelmsland. Hatzfeldthafen [4²4'15"S 145²'12'30"E], 1886, Hollrung 93 [+illegible suffix] (K!); MOROBE: Near Labu, 6 ${ }^{\circ} 45^{\prime S} 146^{\circ} 57^{\prime E}, 5$ June 1962, Hartley T.G.H. 10,290 (A!, L!, P!-image seen);
Coast of Huon Gulf about 5 miles NE of Lae [6 $42^{\circ} 45^{\prime \prime S}$ $147^{\circ} 4^{\prime} 0^{\prime \prime E}$ ], 4 Jan. 1963, Hartley. T.G.H. 11,075 (A!, K!, L!); Neu-Guinea: Kaiser Wilhelmsland. Finschhafen [6 $35^{\prime} 45^{\prime \prime}$ 14751'15"E], 1886, Hollrung 93 (K!, P!-image seen); Awayagi Is. (Fly Is. group), $7^{\circ} 45^{\prime} \mathrm{S} 147^{\circ} 35^{\prime} \mathrm{E}$, sea level, 14 Nov. 1976, Moi 136 (K!, L!); Singawa Coconut Estate, $6^{\circ} 45^{\prime S} 147^{\circ} 0^{\prime} \mathrm{E}$, Feb. 1976, Verdcourt $\mathcal{E}{ }^{\circ}$ Katik 4965 (K!, L!); Kaiser Wilhelmsland. Bumi Mündung [6 $6^{\circ} 35^{\prime} 15^{\prime \prime S}$ 14749'15"E], 1889 - 1891, Weinland 279 (L!); WEST NEW BRITAIN: Kandrain subdistr.., Fullerborn Harbour, 6 $8^{\prime} 0^{\prime \prime S}$ $150^{\circ} 36^{\prime} 45^{\prime \prime}$, sea level, Sayers 21704 (A!, K!, L!). PHILIPPINES. LUzON: Centro de Luzon, s.a., Vidal 1117 (K!, L!); Isabela,

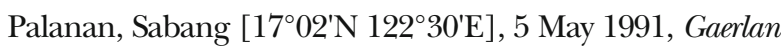
PPI 2986 (K!); Quezon, Infanta [1443'N 121 39'E], s.a., Narciso 37293 (L!); MINDANAO: Zamboagan Province, Sept. 1922, Merrill 11626 (K!); Samboacan, s.a., Perrottet 9 [L!]; SIARGAO: Headland several km W of Dapa in Bo. San Fernando [945'30"N 12603'05"E], 5 m, 1 June 1993, Stone PPI 12111 (KEP!); TAWl-TAWI: Bud Siloan, Bakhawbakhaw, Languyan [5¹8'N 120 07'E], 5 May 1991, Gaerlan

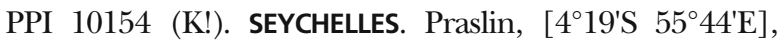
Sept. 1871, Horne 376 (K!). SINGAPORE. Pulau Sakeng [1 ${ }^{\circ} 12^{\prime} 15^{\prime \prime N} 103^{\circ} 46^{\prime} 15^{\prime \prime E}$ ], 22 Sept. 1950, Sinclair 39006 (E!, L!, P!-image seen); Serangoon R. [1 ${ }^{\circ} 23^{\prime} 0 \mathrm{~N} 103^{\circ} 54^{\prime} 15^{\prime \prime E}$, 1898, Ridley 9151 (E!, K!). SOLOMON ISLANDS. BARORA ISLAND: Isaisao Pt. Area [7²9"S 158 18'E], 4 Sept. 1969, Mauriasi $\mathcal{E} \sigma$ collectors BSIP 16574 (K!); CHOISEUL: Easternmost Choiseul, steep hillside at coast opposite Bembalama Island [7²0'45"S 157'33'30"E], 3 March 1964, Whitmore BSIP 4022 (K!); KOLOMBANGARA ISLAND: S of Bambari Harbour [8 $6^{\prime} 157^{\circ} 11^{\prime} \mathrm{E}$ ], 6 Jan. 1968, Gafui $\mathcal{E}^{\circ}$ collectors BSIP 7536 (K!); MALAITA: Su'u Area, South-East Malaita [94'45"S 161 10'0"E], 3 Dec. 1968, Mauriasi E collectors BSIP 13620 (K!); NEW GEORGIA: 2 Sept. 1929, Waterhouse 346 (K!); Baga Island [749'"S 156 32'E], 4 Feb. 1964, 
Whitmore's collectors BSIP 2925 (K!); OEMA ISLAND: SouthEast Oema Island [6 41'30"S 1566'15"E], 1 April 1969, Mauriasi $\mathcal{E}$ collectors BSIP 13790 (K!); REEF ISLANDS: Nanienubuli [10 $10^{\circ} 8^{\prime} 0^{\prime \prime} 166^{\circ} 14^{\prime} 300^{\prime E}$ ], 6 Feb. 1965, Inimua BSIP 6541 (K!); SANTA ISABEL ISLAND: Maringe [ $8^{\circ} 10^{\prime} \mathrm{S}$ 159 35'E], 23 Nov. 1932, Brass 3197 (A!); SW of Paehena Pt., NW Sta Ysabel, on low ridge [7³3'0"S 158 $\left.36^{\prime} 15^{\prime \prime E}\right], 1$ Dec. 1965, Beers's collectors BSIP 7096 (K!); Binusa N.W. Santa Ysabel [7³8'S 158 46'E], 18 Jan. 1966, Beers's collectors BSIP 6792 (K!). THAILAND. PHANG-NGA: Koh Kaw Khao island [Ko Kho Khao] [8 $56^{\prime} \mathrm{N} 98^{\circ} 17^{\prime} \mathrm{E}$ ], 15 July 1972, Larsen 31011 (BFK!, K!, L!, P!-image seen). VANUATU. Éfaté, Mosso, Sounaï [17 $\left.30^{\prime} 45^{\prime \prime S} 168^{\circ} 17^{\prime} 45^{\prime \prime E}\right], 0$ m, 28 Sept. 2014, Ramon 167 (P!-image seen).

HABITAT. Mangroves, tropical and subtropical moist broadleaf forests; alt. $0-20 \mathrm{~m}$.

CONSERVATION STATUS. Least Concern (LC). Smythea lanceata has a very large distribution, with many specimens from many locations - including several very recent collections, and does not meet any criteria to justify threatened status.

PHENOLOGY. Collected in fruit and flower throughout the entire year.

NOTES. Smythea lanceata is recognised by its crustaceous, inflated, [narrow-] ovate, wingless fruit with an attenuate to acuminate apex, and is the only known species of the tribe with pocket domatia. Smythea lanceata is also recognised by the \pm smooth nectary disks, as opposed to the distinctly papillose nectary disks of many of the other members of Smythea that had flowers available for study: S. bombaiensis, S. macrocarpa, S. velutina and S. oblongifolia. S. lanceata is most similar to $S$. poomae in having crustaceous, inflated, wingless fruit but differs in the $3-5$ pairs of secondary veins, wellspaced along the primary vein, with especially the veins midway along sometimes separated by up to a third of the total lamina length, the conspicuous domatia and the ovate fruit with an even shape near the base and an attenuate to acuminate apex.

Unfortunately, the type material of Tulasne has not been traced. Ventilago lanceata was described by Tulasne based on a collection by Pervillé who visited the Seychelles in the early 1840s. These collections were deposited in P, but we have been unable to locate the specimen in Paris (P. Lowry, pers. comm.), and, in addition, Stafleu \& Cowan (1986: 530) note that Tulasne's types are at FI but the specimen is not located there (Chiara Nepi, pers. comm.); in addition, the Harvard University Herbaria Botanist database lists Pervillé specimens at $\mathrm{L}$ and $\mathrm{B}$, but no Rhamnaceae specimens from the Seychelles were found at either institute. It is interesting that in the first Flora of The Seychelles, Baker (1877: 11), twenty years after the first publication of $V$. lanceata, noted that in writing the Flora, Kew had received some specimens from "the Paris Museum, the latter gathered by M. August Pervillé" but describes only Colubrina asiatica Brongn. from the Seychelles and does not mention Ventilago within the Flora account. On making the combination to Smythea, Summerhayes (1928) noted "there seems no doubt from the description [of $V$. lanceata] that Tulasne's species is identical [with $S$. dupontii and S. pacifica]". In his subsequent updated list of the flora of the Seychelles, Summerhayes (1931: 273) also cites Pervillé 126 but without an exclamation mark. Both of these statements indicate that he is following previous publications and had not seen the specimen himself. We have selected the Dupont 17 specimen as a neotype because it has flowers and young fruits, whereas the sheet of Horne 376 is sterile; there can be no doubt as to the identity of the either of these specimens, but the latter one is less informative for identification purposes.

Examination of Gaudichaud 111, the type of Ventilago cernua, show several characters that place it within the morphological range of Smythea lanceata. With the presence of pocket domatia, $3-5$ pairs of secondary veins, which are sometimes separated by up to a third of total lamina length, and visible vein reticulations on both sides of the leaf, the specimen has the range of leaf characters of $S$. lanceata.

7. Smythea macrocarpa Hemsl. (Hemsley 1887: t. 1558). Type: Malaysia, Peninsular Malaysia, Perak, Larut [Taiping], Waterfall Hill, s.a., Wray 36 (lectotype, selected here: K! [K000681974]; isolectotype: K! [K000681973]).

Smythea lancifolia Ridl. (Ridley 1924: 295), synon. nov. Type: Malaysia, Peninsular Malaysia, Penang, Highlands Hill, $1500 \mathrm{ft}$ [450 m], 22 May 1923, Haniff 9142 (lectotype, here designated: K! [K000681972]; isolectotype: SING! [SING0059220]).

DISTRIBUtION. Malay Peninsula, Borneo, Sumatra and Thailand. Map 4.

ADDITIONAL SPECIMENS EXAMINED. BRUNEI. BELAIT, Sukang, Kampong Sukang, $4^{\circ} 19^{\prime} \mathrm{N} 114^{\circ} 37^{\prime} \mathrm{E}, 21 \mathrm{Ju}-$ ly 1993, Atkins et al. 518 (K!); Kuala Balai [4³5'N 114²13'E], 2 July 1935, Ja'amat bin Keling. 39697 (KEP!). INDONESIA. SUMATRA: Aceh, Gunung Leuser Nature Reserve, near tributary of Lau Ketambe, c. $35 \mathrm{~km}$ NW of

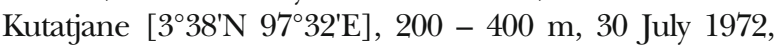
Wilde $\mathcal{E}^{\circ}$ Wilde-Duyfjes 13903 (K!, KEP!, L!); ibid., 26 March 1975, Wilde E Wilde-Duyfjes 15887 (A!, K!, KEP!, L!). MALAYSIA. PENINSULAR MALAYSIA: FEDERAL TERRITORY

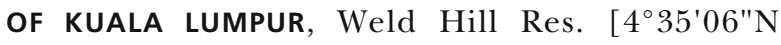
114²13'26"E], 6 Aug. 1918, Ah Mat 2481 (KEP!); КEDAH, Inchong Estate $\left[5^{\circ} 10^{\prime} \mathrm{N} 100^{\circ} 37^{\prime} \mathrm{E}\right], 25 \mathrm{ft}[10 \mathrm{~m}], 3$ Sept. 1941, Spare Singapore Field No. 37612 (A!, K!); KELANTAN, Sg. Lebir eastern bank opp. Jentah [5 ${ }^{\circ} 1$ N $102^{\circ} 23^{\prime} \mathrm{E}$ ], 28 April 1976, Stone $\mathcal{E}^{\circ}$ Sidek 12517 (L!); PERAK, Larut [Taiping], Waterfall Hill [4 $4^{\circ} 51^{\prime} \mathrm{N} 100^{\circ} 47^{\prime} \mathrm{E}$ ], $2000 \mathrm{ft}$ [600 m], June 1888, Wray 2211 [K!]; Larut [Taiping] 


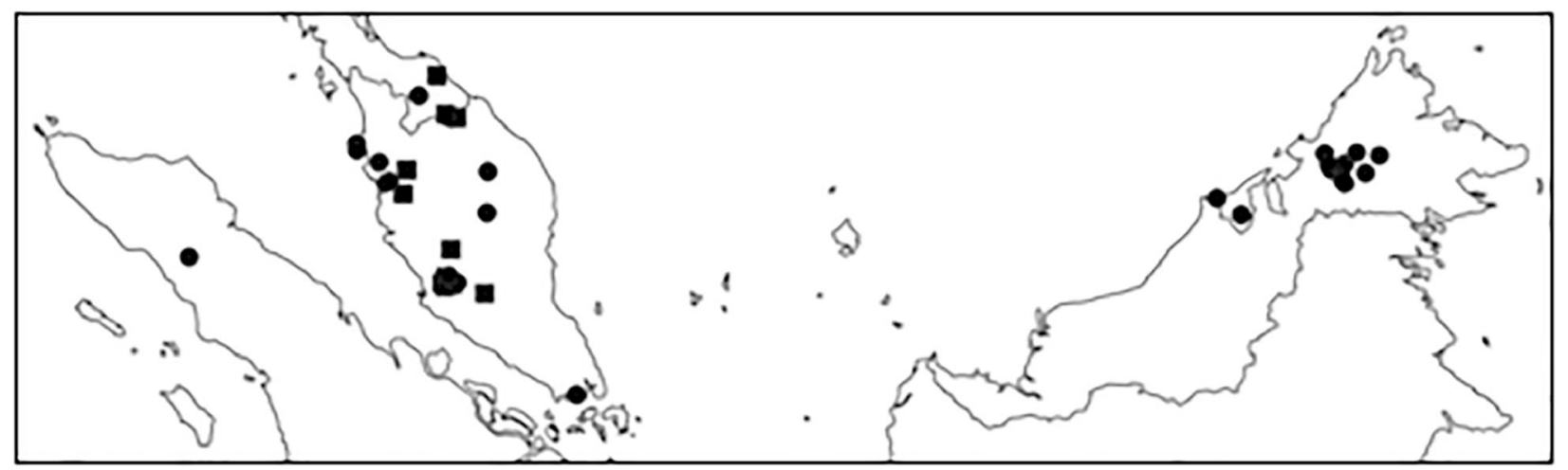

Map 4. Distribution of Smythea macrocarpa $(\bullet)$ and S. velutina ( $\mathbf{\bullet})$.

[4 $\left.50^{\circ} \mathrm{N} 100^{\circ} 44^{\prime} \mathrm{E}\right]$, to $300 \mathrm{ft}[100 \mathrm{~m}]$, Dec. 1882, King's Collector 3628 (E!); ibid., Nov. 1882, King's Collector 3596 (L!, P!-image seen); ibid., Sept. 1882, King's Collector 3334 (E!); ibid., Aug. 1882, King's Collector 3154 (P!-image seen); ibid., Feb. 1882, King's Collector 2817 (K!, L!); PENANG, Batu Ferengy [5 $28^{\prime} 0^{\prime \prime} \mathrm{N} 100^{\circ} 15^{\prime} 0^{\prime \prime E}$ ], March 1892, Curtis 2780 (K!, SING-5 sheets!); SELANGOR, $12^{\text {th }}$ mile Gombak [319'N 101 ${ }^{\circ} 45^{\prime} \mathrm{E}$ ], 9 June 1926, Strugnell 11147 (K!); Ulu Langat, K. Pansom [3 12'45"N 101 53'0"E], 20 April 1960, Gadoh anak Umbai 2119 (KEP!). SABAH: KENINGAU, Sook [5 $8^{\prime} 30^{\prime \prime} \mathrm{N} 116^{\circ} 18^{\prime} 15^{\prime \prime E}$, 5 Dec. 1972, Heya 72488 (K!, L!); Mendalom FR area [5 $\left.4^{\prime} \mathrm{N} 116^{\circ} 6^{\prime} \mathrm{E}\right], 23$ Sept. 1986, Krispinus SAN 116699 (K!, KEP!, L!); Logging area Lanas [5¹9'30"N 116 29'45"E], 14 July 1987, Krispinus SAN 119608 (E!, K!, KEP!); Logged Area Pisagon [5 $6^{\prime} \mathrm{N}$ $\left.116^{\circ} 16^{\prime} \mathrm{E}\right]$, 24 June 1989, Sumbing SAN 127672 (KEP!); NABAWAN, Pensiangan Kayu F. Res. [450'N 116 18'E], 9 July 1992, Mantor SAN 130075 (E!, K!, KEP!); H.S. Ponontomon [ $4^{\circ} 53^{\prime} \mathrm{N} 116^{\circ} 16^{\prime} \mathrm{E}$ ], 18 July 1991, Mantor SAN 131530 (K!); TENOM, Tinutudan, Melalap Tenom [5¹9'N 11559'E], 11 July 1995, Jimpin SAN 139252 (K!, KEP!); TONGOD, Logged Area Pisagon [506' N 116 ${ }^{\circ} 16^{\prime} \mathrm{E}$ ], 17 June 1989, Krispinus SAN 127611 (E!, KEP!); Hutan Simpan Mandalom [5 $\left.08^{\prime} \mathrm{N} 116^{\circ} 02^{\prime} \mathrm{E}\right], 16$ Aug. 1993, Krispinus SAN 136138 (KEP!); Ulu Sungai Melikop [50'N 116 $38^{\circ} \mathrm{E}$ ], $500 \mathrm{~m}$, 1 June 1985, Sundaling et al. SAN 109264 (K!); Kpg. Saguan, Pinangah [5¹7'N $\left.116^{\circ} 52^{\prime} \mathrm{E}\right], 150 \mathrm{~m}, 8$ July 1981, Sundaling SAN 93192 (L!). SINGAPORE. Nee Soon [ $\left.1^{\circ} 23^{\prime} 45^{\prime \prime} \mathrm{N} 103^{\circ} 49^{\prime} 30^{\prime \prime E}\right], 5 \mathrm{~m}$, 1 April 1981, Maxwell 81-64 (L!). THAILAND. PATTANI: Banang Sta. [6 ${ }^{\circ} 15^{\prime} \mathrm{N} 101^{\circ} 16^{\prime} \mathrm{E}$ ], 15 June 1930, Kiah 24342 (K!); ibid., 100 m, 25 July 1923, Kerr 7320 (E!, K!).

HABITAT. Lowland rain forests of the Malay Peninsula and Borneo, at lower altitudes and in valleys of Peninsular Malaysian and Sumatran montane rain forests; alt. $0-600 \mathrm{~m}$.

CONSERVATION STATUS. Near Threatened (NT). The taxon is very likely declining and its habitat is severely fragmented given widespread destruction of much of its habitat, especially in the lowland rainforests of Borneo and the Malay Peninsula (Loucks 2001). However, with an EOO greater than $30,000 \mathrm{~km}^{2}$, the taxon does not currently qualify as threatened as it is widely distributed and there are several collections from the 1990s.

PHENOLOGY. Collected in flower from February to April, June and Sept.; collected in fruit in March, from May to Sept., Nov. and Dec.

NOTES. Smythea macrocarpa is recognised by its subglabrous fruit borne in the axils of persistent leaves, moderately to conspicuously prominent secondary veins on the abaxial leaf surface and secondary vein pairs separated from each other by no more than a fifth of total lamina length. Variation in the number of secondary veins in leaves of a single branchlet, e.g. 3 to 9 pairs on a single branchlet of Wray 36, is a trait shared only with S. velutina. The only other taxa of Smythea found in the Malay Peninsula are S. lanceata, S. oblongifolia and S. velutina, and the only other taxa of Smythea recorded from Borneo are S. lanceata, S. oblongifolia and S. hirtella. The overall morphology of $S$. macrocarpa is very similar to that of $S$. velutina but $S$. macrocarpa differs in the glabrous abaxial leaf surfaces and fruit, although mature fruit may be sparsely hairy near their base. It differs from S. lanceata in the elliptic to oblong wing-like fruit shape, in the more numerous and conspicuously prominent secondary veins and in the more distinct leaf margin serration. Prominent secondary veins on the abaxial side and conspicuous domatia can also be found in $S$. oblongifolia, but S. macrocarpa differs in its flower fascicles being located in the axils of persistent leaves and in its secondary veins ascending less acutely and not readily forming secondary vein branch loops near the more finely serrated leaf margins. Smythea macrocarpa differs from S. hirtella in the flower fascicles and fruit being borne in the axils of persistent leaves and its smaller petiole to lamina length ratio.

Ridley (1924) named Smythea lancifolia based on Penang specimens with narrow fruit and narrower and generally smaller leaves and, indeed, the fruit from the type of $S$. macrocarpa are much wider than specimens collected from Penang. However, with more material available now than when Ridley published S. lancifolia, considerable variation in S. macrocarpa fruit size and shape can be observed. Some specimens have 
mature elliptic fruit c. 3 times longer than wide (Wray 36) while others have mature oblong fruit more than 6 times longer than wide (Wray 2211). In addition, the remaining leaves on the Penang specimens are mostly distal. This would account for their being narrower and smaller. It would appear that the two K specimens of Wray 36 are not duplicates despite having the same collection number, because the flowering specimen notes that a fruiting specimen was sent earlier. However, because the protologue describes both flowers and fruits and, as one of these specimens is only in flower with the other only in fruit, both were used to write the protologue and lectotypification is required.

Occurrences of Smythea macrocarpa in Borneo and Sumatra presented here are new. All Bornean specimens of $S$. macrocarpa have hitherto been identified as belonging to Ventilago despite their fruit having an inconspicuous, flattened and elongated seed chamber. Rup Chand 6177 from Meghalaya, India, was identified as S. macrocarpa by Banerjee \& Mukherjee (1970: 214), but its leafless racemes and oblong leaves with little variability in the number of secondary vein pairs, and secondary vein branches readily forming loops near the leaf margin reveal that it belongs to $S$. oblongifolia.

\section{Smythea oblongifolia (Blume) Cahen $\mathcal{E}$ Utteridge comb. nov.}

http://www.ipni.org/urn:lsid:ipni.org:names:77165444-1

Ventilago oblongifolia Blume, Bijdr. Fl. Ned. Ind. 17: 1144 (1826). Type: Indonesia, Java, Tjerimai [Mount Cereme], s.a., Blume 137i (lectotype, selected here: L! [L0013785]; isolectotypes: GH!, L-3 sheets! [L0013784; L0013786; L0013787]).

Ventilago luzoniensis S. Vidal (1886: 90), synon. nov. Type: Philippines, Luzon, Tarlac, La Paz, s.a., Vidal 198 (lectotype, selected here MA!-image seen [MA472763]; isolectotypes: K! [K000681913], L! [L0551994]).

Ventilago fascigera Pierre (1894: t. 314d), synon. nov.

Type: Vietnam, insula Phu Quôc [10²1'N $103^{\circ} 54^{\prime} \mathrm{E}$ ], Feb. 1874, Pierre 4045 (lectotype, selected here: P!-image seen [P06788720]; isolectotype: P!image seen [P06788718]).

Ventilago ochrocarpa Pierre (1894: t. 313b), synon. nov. Type: Cambodia, Preah Vihear, in prov. Mulu Prey [13ㄴㅇ' $\left.105^{\circ} 16^{\prime} \mathrm{E}\right]$, Jan. 1876, Harmand 300 (lectotype, selected here: P!-image seen [Pierre 5834=P06765574]; isolectotypes: P!-image seen [P06765577; Pierre 5834=P06765579]).

DISTRIBUtION. Cambodia, China (Guangxi, Yunnan), India (Andamans, Meghalaya), Indonesia (Java, Lesser Sunda Islands, Malaku, Riau Islands, Sumatra), Laos, Malaysia (Peninsular Malaysia, Sabah), Philippines (Luzon, Mindoro, Palawan), Thailand, Vietnam. Map 5.
SPECIMENS EXAMINED. CAMBODIA. PREAH VIHEAR: in prov. Mulu Prey [13 $\left.48^{\prime} \mathrm{N} 105^{\circ} 16^{\prime} \mathrm{E}\right]$, Jan. 1876, Harmand 300 (P!-image seen). INDIA. ANDAMANS: South Andaman, Port Mouat hill jungle [11 $37^{\prime} \mathrm{N}$ 92 ${ }^{\circ} 37^{\prime E}$ ], 15 Feb. 1891, King s.n. (K!); MEGHALAYA: Cherrapunjee, Khasi Hills [25 $\left.17^{\circ} \mathrm{N} 91^{\circ} 42^{\prime} \mathrm{E}\right], 4000 \mathrm{ft}$ [1200 m], 20 July 1952, Rup Chand 6177 (L!). INDONESIA. JAVA: Tjerimai [Mount Cereme], s.a., Blume 137i (GH!, K!, L!); Cianjur Regency, Res. Priangan Mt Garden Tjibodas, near camphor garden, $1450 \mathrm{~m}, 7$ Nov. 1953, van Steenis 17851 (A!, K!, L!); LESSER SUNDA ISLANDS: EAST NUSA TENGGARA, Flores, Lita, Waewako [843'S 1206'E], 21 Aug. 1973, Schmutz 3356 (L!); ibid., Mbelé Creek between Paku and Tjereng, 400 m, 20 July 1972, Schmutz 3002 (L!); ibid., Téngku - Dila (Ruis) [8³4'S 120²8'E], 17 Jan. 1973, Verheijen 3242 (L!); Sumba [942'S 11958'E], 15 July 1974, Verheijen 3945 (L!); Timor, Kupang, Amarasi Barat, Desa Soba, $10^{\circ} 16.74 ' \mathrm{~S} 123^{\circ} 44.05^{\prime} \mathrm{E}, 11$ Aug. 2011, Made Maduarta IMM 168 (K!); WEST NUSA TENGGARA, Sumbawa, Mt Batulanteh, Sampar Olat, Batu Burung ridges, $\mathrm{N}$ of Batudulang [ $8^{\circ} 35^{\prime} \mathrm{S} 117^{\circ} 17^{\prime} \mathrm{E}$ ], 500 - $600 \mathrm{~m}, 30$ April 1961, Kostermans 18583 (A!, K!, L!, P!-image seen); MALAKU, Halmaheira, Sosoepol, Kp. Taroeba [1 ${ }^{\circ} 10^{\prime} 15^{\prime \prime} \mathrm{N}$ 127⒉5'30"E], 50 m, Nedi 222 (L!); Sanana, langs kali Tandjong Baliha [2 $\left.{ }^{\circ} 24 ' \mathrm{~S}, 126^{\circ} 3^{\prime} \mathrm{E}\right], 15 \mathrm{~m}, 29$ July 1939, Bloembergen 4417 (L!); RIAU ISLANDS, Anambas, Siantan, Tarempah [ $3^{\circ} 12^{\prime} \mathrm{N} 106^{\circ} 12^{\prime} \mathrm{E}$ ], sea level, 1 April 1928, Henderson Singapore Field No. 20171 (K!, L!); SUMATRA, Limestone hill near Halaban, Pajakumbub region $\left[0^{\circ} 20^{\prime} \mathrm{S}\right.$ $100^{\circ} 47^{\prime} \mathrm{E}$ ], 700 m, 2 Sept. 1957, Maradjo 404a (L!). LAOS. Bassin du Sè-Moun (Laos méridional), 1875 - 1877, Harmand s.n. (P!-image seen). MALAYSIA. PENINSULAR MALAYSIA: KELANTAN, Ulu Langat, Bukit Penown, K. Pansom [3 ${ }^{\circ} 13^{\prime} \mathrm{N} 101^{\circ} 53^{\prime} \mathrm{E}$ ], 11 Oct. 1958, Umbai 1043 (KEP!); PERLIS, Cuping, Sg. Air Jernih, picnic area $\left[6^{\circ} 32^{\prime} \mathrm{N} 100^{\circ} 16^{\prime} \mathrm{E}\right], 23$ Aug. 1991, Zainudin 3840 (K!); SELANGOR, Batu Caves [ $3^{\circ} 15^{\prime} \mathrm{N} 101^{\circ} 41$ 'E], 1908, Ridley 13349 (K!); SABAH: KINABATANGAN, Tempai, near the seashore [5 $30^{\prime} \mathrm{N} 118^{\circ} 50^{\prime} \mathrm{E}$ ], 27 Jan. 1932, Mail 1655 (K!); LAHAD DATU, Lahad Datu Dam, $25 \mathrm{ft}$ [0 m], 17 Sept. 1983, Mail 3648 (K!); TAWAU, Benaword [4²4'N 117³3'E], 24 April 1980, Fedilis No. SAN 91829 (K!, KEP!, L!); Maldai Caves, Trail to the summit [ $4^{\circ} 44^{\prime} \mathrm{N}$ $\left.118^{\circ} 8^{\prime} \mathrm{E}\right], 10$ June 1996, Berhaman 86 (K!, KEP!). PHILIPPINES. LUZON: CAGAYAN, Peña Blanca [17 $40^{\prime} \mathrm{N}$ $122^{\circ} 0^{\prime} \mathrm{E}$ ], April 1926, Ramos Eं Edaño FB 46648 (K!); ibid., March - May 1929, Ramos FB 76819 (K!); ILOCOS NORTE, Burgos [18 28'N 120 39'E], Feb. - March 1917, Ramos FB 27197 (K!, P!-image seen); LAGUNA, Mt Makiling [1408'N 121 ${ }^{\circ} 12^{\prime} \mathrm{E}$ ], April 1914, Villamil FB 21408 (K!); ibid., 100 m, 5 Feb. 1956, Sulit 35801 (L!); RIZAL, Montalban [14 $46^{\prime} \mathrm{N}$ $\left.121^{\circ} 15^{\prime} \mathrm{E}\right]$, s.a., Loher 5823 (K!); TARLAC, La Paz [15²7'N 12043'E], s.a., Vidal 198 (K!, L!). MINDORO: Paluan [13⒉5'N 120³1'E], April 1921, Ramos FB 39822 (K!, L!, P!-image seen); PALAWAN: Palawan, Dec. 1905, Bermejos 


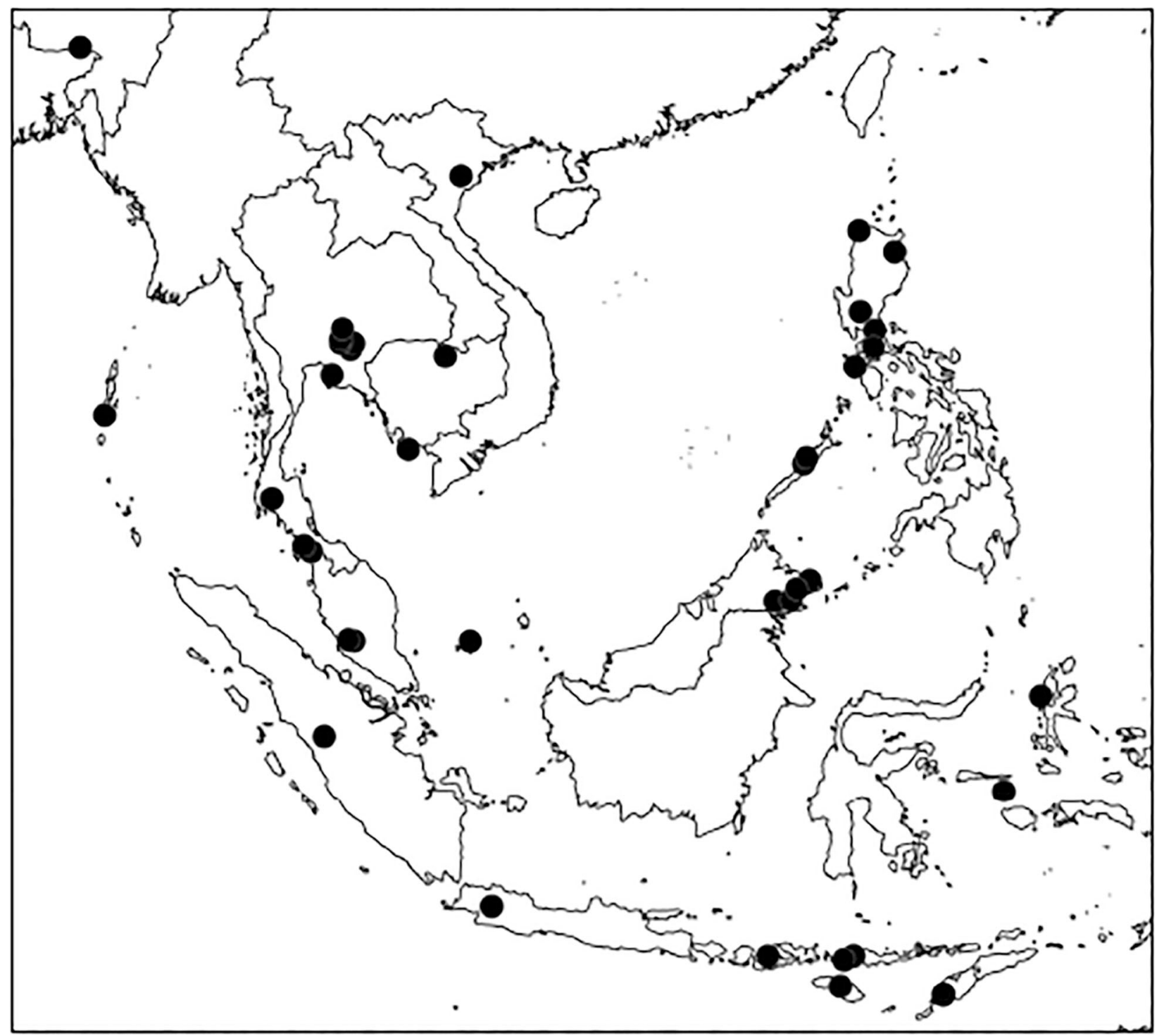

Map 5. Distribution of Smythea oblongifolia $(\bullet)$.

BS No 264 (K!); Puerto Princesa, Mt Pulgar [948'N 118 36'E], April 1911, Elmer 12921 (K!, L!, P!-image seen). THAILAND. CHANTHABURI: Khao Soi Dao Wildlife Sanctuary, $13^{\circ} 05^{\prime} 33.10^{\prime \prime} \mathrm{N} 102^{\circ} 10^{\prime} 21.20^{\prime \prime E}, 370 \mathrm{~m}, 16$ May 2013, Tagane et al. 1484 (BKF!); CHON BURI: Sriracha Forest [13 $06^{\prime} \mathrm{N} 101^{\circ} 04^{\prime} \mathrm{E}$ ], about $80 \mathrm{ft}$ [0 m], 23 Nov. 1927, Collins 1723 (K!, L!); KRABI: Kao Sataw [ $8^{\circ} 30^{\prime} \mathrm{N} 98^{\circ} 50^{\prime} \mathrm{E}$ ], c. 50 m, 25 March 1927, Kerr 12427 (K!, L!); NAKHON NAYOK: Kow Yai National Park, Hin Dahng subdistrict, Maw Sing Dto area $\left[14^{\circ} 25^{\prime} \mathrm{N} 101^{\circ} 23^{\prime} \mathrm{E}\right], 825 \mathrm{~m}, 17$ Nov. 2002, Maxwell 02-777 (A!); ibid., c 1 km W of Hayo Sawat Falls, 625 m, 15 Dec. 2006, Maxwell 06-975 (A!); NAKHON RATCHASIMA: Tachang, Chantuk [Chan Thuek], [14 $49^{\prime} \mathrm{N} 101^{\circ} 28^{\prime} \mathrm{E}$ ], c. 400 m, 7 Jan. 1925, Kerr 9876 (E!, K!); PRACHIN BURI: Ban Keng [Ban Kaeng]
[14 $\left.4^{\circ} \mathrm{N} 101^{\circ} 45^{\prime} \mathrm{E}\right]$, c. 25 m, 11 Nov. 1930, Kerr 19838 (K!, L!, P!-image seen); Bupram [Bu Phram] [14 $17^{\prime} \mathrm{N}$ $101^{\circ} 52 ' \mathrm{E}$ ], c. 300 m, 3 Jan. 1925, Kerr 9827 (K!, L!); Khao Yai N.P., Haew Nerok Fall [141'N 101 23 'E], c. 350 m, 11 Jan. 1999, Wongprasats.n. (BKF!); SATUN: Kuan Po [Khuan Pho] [6 ${ }^{\circ} 46^{\prime} \mathrm{N} 100^{\circ} 1 ' \mathrm{E}$ ], c. 20 m, 1 Jan. 1928, Kerr 13824 (K!, L!, P!-image seen). VIETNAM. HA NAM: Kiên Khê, in montibus Dong Bau [20³0'N 10552'E], 11 Nov. 1883, Bon 2274 (P!-image seen); PHU QUOC: insula Phu Quôc [10²1'N 103 54'E], Feb. 1874, Pierre 4045 (P!-image seen). HABITAT. Tropical habitats including lowland moist broadleaf forests and dry forests, and montane rain forests; alt. $0-1450 \mathrm{~m}$.

CONSERVATION StATUS. Least Concern (LC). Smythea oblongifolia is widely distributed across South-East Asia and is not threatened. 

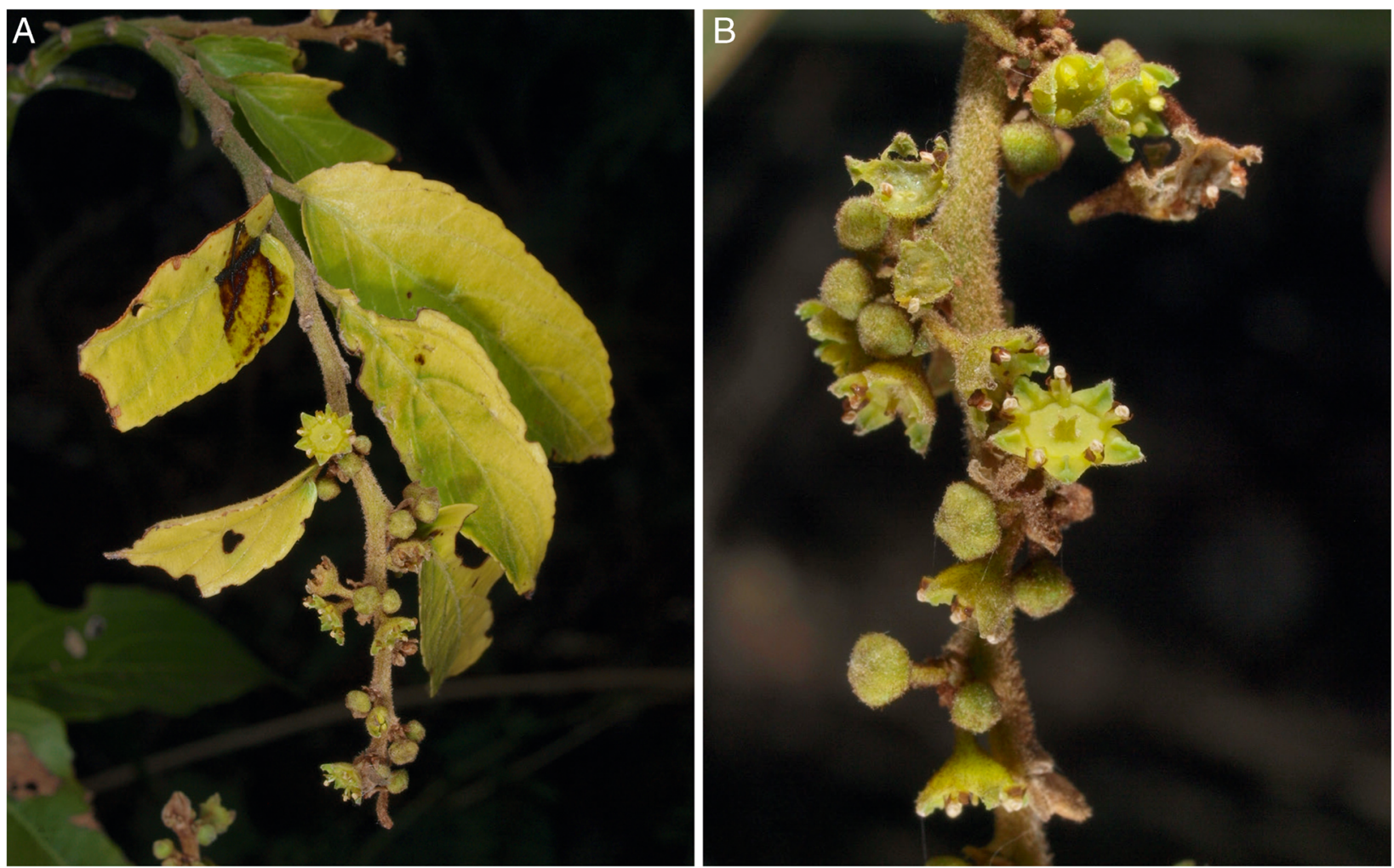

Fig. 5. Smythea oblongifolia. A habit, showing distal portion of inflorescence with fascicles not subtended by leaves; B flower detail. A, B from Made Maduarta IMM 168. PHOTOs: TIMOTHY UTTERIDGE.

PHENOLOGY. Collected in flower in Jan., April, July and Sept. to Dec.; collected in fruit from Jan. to April, July and Nov. NOTES. Smythea oblongifolia is recognised by the flower fascicles and fruit borne in leafless racemes or panicles (Fig. 5), and the $5-7$ pairs of conspicuously prominent secondary veins diverging from the primary vein at usually $20-35^{\circ}$, the narrowest angles of divergence for secondary veins in Smythea. The only other taxon of Smythea which shares the leafless raceme character is S. hirtella and both taxa can be found in Sabah. However, S. oblongifolia differs in its conspicuously prominent secondary veins, which are connected by secondary vein branches forming distinct loops near the leaf margin, its conspicuous domatia and its shorter relative petiole length.

Smythea oblongifolia was originally placed in Ventilago as $V$. oblongifolia by Blume (1826). Its fruit have a winglike apical appendage - a character that is shared by all Ventilagineae except $S$. lanceata and $S$. poomae. However, S. oblongifolia unequivocally presents a flattened seed chamber, which is a diagnostic character for members of Smythea (Weberbauer 1895; Lauterbach 1922; Suessenguth 1953; Banerjee \& Mukherjee 1969, 1970). In addition, S. oblongifolia fruit are slightly twisted near their base and their flowers have distinctly papillose nectary disks; characters, except for S. lanceata and S. poomae, considered here to be typical for Smythea. Note, from the four sheets available in Nationaal Herbarium Nederland, L0013785 is chosen as the lectotype here because it has both fertile and vegetative shoots and, in addition, seemingly has an original collecting slip mounted on the sheet.

Merrill (1909) noted that Ventilago luzoniensis specimens resemble $S$. oblongifolia, but differ in their shorter leaves. Specimens of $V$. luzoniensis examined here, including the type specimen (Vidal 198), appear identical to those of S. oblongifolia. These specimens of $V$. luzoniensis retain mostly distal leaves which could account for their smaller size, which, regardless, is still within the range observed for S. oblongifolia. According to Stafleu \& Cowan (1986: 727), Vidal's top set of specimens are in Madrid (although duplicates were sent to many other herbaria), and therefore, the MA specimen is selected as lectotype here.

Study of the descriptions and type specimens of Ventilago ochrocarpa and $V$. fascigera, confirm that $V$. ochrocarpa corresponds to Smythea oblongifolia and that $V$. fascigera corresponds to a distal branch of S. oblongifolia with immature fruit. From the three specimens of $V$. ochrocarpa available as syntypes in $\mathrm{P}$, we have selected a specimen from Pierre's herbarium which he has given his number but it clearly states on the label that it was collected by Harmand - both numbers are given in the protologue and in the type citation above. 
Occurrence of Smythea oblongifolia in India had not hitherto been reported, but Kings.n from South Andaman, identified as S. calpicarpa by Banerjee \& Mukherjee (1970: 213), and Rup Chand 6177 from Meghalaya, identified as S. macrocarpa by Banerjee \& Mukherjee (1970: 214), are best determined as $S$. oblongifolia because of the leafless racemes, narrow-acute angle of divergence and secondary vein branches forming distinct loops near the leaf margin.

9. Smythea poilanei Cahen $\mathcal{E}$ Utteridge sp. nov. Type: Laos, Vientiane Prefecture, Ban Tha Ngon Road [18 $\left.5^{\circ} \mathrm{N} 102^{\circ} 40^{\prime} \mathrm{E}\right], 170 \mathrm{~m}, 1$ Oct. 1955 , de Malahide 88 (holotype K! [K000606765]; isotypes K! [K000606766], SING).

http://www.ipni.org/urn:lsid:ipni.org:names:60475115-2

Climbing shrub 6-8 m long. Indumentum dense at distal end of branchlets with subappresed, antrorse, fulvous hairs. Branches slender, slightly angular, smooth, greyish-brown; branchlets ridged, with a transparent outer layer sometimes peeling in thin translucent strips. Stipules fugaceous, occasionally persistent and seen at fruiting stage, linear, hairy. Leaves: blade narrow ovate, $1.5-8.5 \mathrm{~cm}$ long, 0.8 $3.8 \mathrm{~cm}$ wide, chartaceous-subcoriaceous, apex attenuate to long acuminate, mucronulate, base asymmetric, rounded to broadly cuneate, margins widely crenate-serrate, obscurely near base, serrations topped by black callosities; veins yellow with a faint reddish tint; primary vein subglabrous, more densely hairy near the base, prominent abaxially; secondary veins $2-4$ pairs, the second pair from the leaf base consistently much closer to the first than to the third pair, weakly to moderately prominent abaxially, sometimes connected by secondary vein branches or directly joining near apex, angle of divergence from primary vein usually $35-45^{\circ}$; domatia conspicuous, hairs on both veins and lamina surface at secondary vein axils; tertiary veins perpendicular to primary vein, spaced every c. $0.5 \mathrm{~mm}$; reticulations indistinct; lamina glabrous abaxially except for domatia, hairy along the primary and some secondary veins on the adaxial side; petiole $1-4 \mathrm{~mm}$ long, hairy. Inflorescence fascicles borne in the axils of persistent leaves; pedicels to $7 \mathrm{~mm}$ long, slender, with very short hairs at an early stage (subglabrous at the fruiting stage); calyx lobes c. $0.7 \mathrm{~mm}$ long, keeled adaxially; nectary disk with short papillae; ovary hairy. Fruit subglabrous to very sparsely hairy, sparsely hairy near base, fruit brown, reddish-brown near base, oblong, $4.0-6.1 \mathrm{~cm}$ long, $0.9-1.3 \mathrm{~cm}$ wide, slightly twisted near base, apex obtuse-rounded. Fig. 6 .

RECOGNITION. Most similar to Smythea batanensis and $S$. beccarii in the number of secondary veins and very sparsely hairy fruit borne in the axils of persistent leaves, but differs in its indistinct high order venation reticulations, in its more closely spaced tertiary veins, separated from each other by $\mathrm{c}$. $0.5 \mathrm{~mm}$, in its second pair of lateral veins starting from the base consistently much closer to the first than to the third pair, and in its leaf blades which have a longer acumen. DISTRIBUTION. Laos: near Vientiane and in Savannakhet area. Map 1.

ADDITIONAL SPECIMEN EXAMINED. LAOS. SAVANNAKHET PROVINCE: Savannakhêt [16 $\left.33^{\prime} 54^{\prime \prime N}, 104^{\circ} 45^{\prime} 10^{\prime \prime} \mathrm{E}\right], 17$ Oct. 1938, Poilane 28.085 (K!, P!-image seen). HABITAT. Central Indochina dry forests (putative); alt. C. $150 \mathrm{~m}$.

CONSERVATION STATUS. Endangered EN B2ab(iii). This species is only known from two collections from two locations (hence, only the AOO of $8 \mathrm{~km}^{2}$ can be calculated: less than EN threshold of $500 \mathrm{~km}^{2}$ using a cell size of $2 \mathrm{~km}$ ), and both relatively historic (the most recent being from 1955). The collections are outside protected areas, and in provinces that have been subject to much habitat conversion with documented continuing clearing of the natural dry forests in Laos (Wikramanayake et al. 2001). Whilst the collection density of Laos is extremely low (see Newman et al. 2007), and there is obviously much uncertainty when estimating threat in such poorly known regions, we have used a precautionary attitude (following IUCN 2012: 23) and, from the information available assume the species is threatened.

PHENOLOGY. Collected in fruit in Oct.

ETYMOLOGY. Smythea poilanei is named in honour of botanist Eugène Poilane (1887 - 1964) who collected specimens in the Savannakhet area in 1938.

NOTES. The only other taxon of Smythea found in Laos is $S$. oblongifolia, which $S$. poilanei differs from in the subglabrous fruit borne in the axils of persistent leaves and the fewer, weakly to moderately prominent secondary veins remaining separate near the leaf margin. Smythea poomae is found in Thailand's Nan Province near the Lao border but differs by its inflated narrow-ovate fruit and by its leaves which have a cuneate to decurrent lamina base and $5-7$ pairs of secondary veins.

10. Smythea poomae Cahen $\mathcal{E}$ Utteridge sp. nov. Type: Thailand, Nan Province, Pua, Doi Phu Kha National Park [19²11'55"N 101 $\left.{ }^{\circ} 4^{\prime} 46^{\prime \prime} \mathrm{E}\right], 1700$ m, 17 Aug. 1995, Pooma 1112 (holotype BKF! [BKF 102045]).

http:/ /www.ipni.org/urn:lsid:ipni.org:names:60475116-2

Climber. Indumentum very sparse except at the distal end of branchlets; hairs spreading. Branches subterete, slightly ridged, smooth; branchlets ridged. Stipules fugaceous. Leaves: lamina elliptic, $3.0-8.1 \mathrm{~cm}$ long, $1.8-3.1 \mathrm{~cm}$ wide, chartaceous-subcoriaceous, apex with a short obtuse acumen, mucronulate, base weakly 


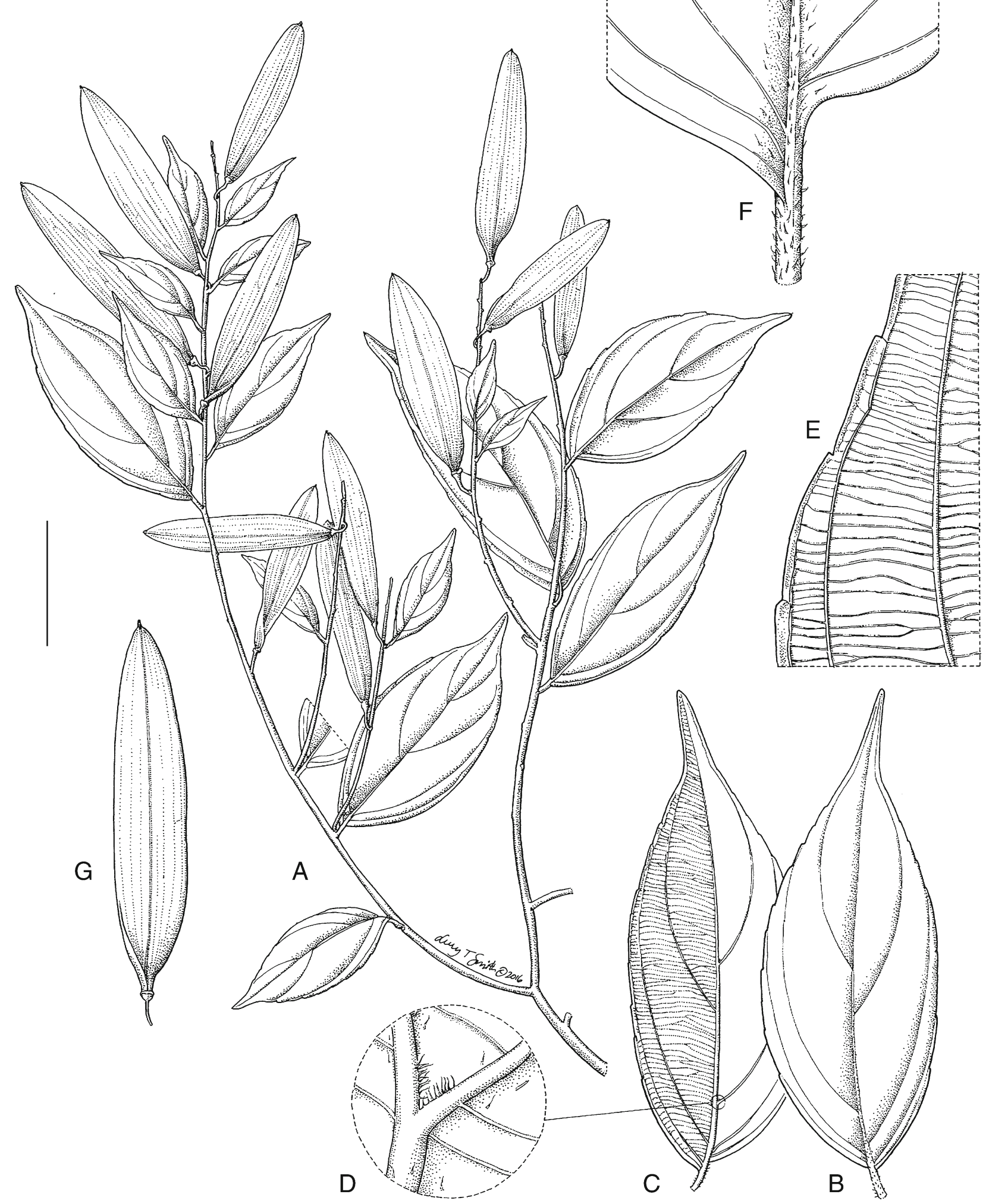

Fig. 6. Smythea poilanei. A habit; B leaf, adaxial view; C leaf, abaxial view; D detail of domatia; E detail of venation, abaxial view; $F$ distal portion of petiole and lamina base; $G$ fruit. Scale bar: $A=3 \mathrm{~cm} ; B, C, G=2 \mathrm{~cm} ; D=1.3 \mathrm{~mm} ; E, F=3.3 \mathrm{~mm}$. All from Talbot de Malahide 88. DRAWN BY LUCY T. SMITH. 
asymmetric, cuneate to decurrent, margins inconspicuously crenate-serrate, serrations topped by callosities; lamina glabrous on both sides; primary vein sparsely hairy on both sides of lamina, prominent abaxially; secondary veins $5-7$ pairs, subglabrous, moderately to conspicuously prominent abaxially, remaining separate near margin or indistinctly connected by secondary vein branches, angle of divergence from primary vein usually $35^{\circ}-55^{\circ}$; domatia inconspicuous; tertiary veins spaced every c. $0.5 \mathrm{~mm}$; reticulations distinct abaxially, inconspicuous adaxially; petiole $2-5 \mathrm{~mm}$ long, sparsely hairy. Inflorescence fascicles borne in the axils of persistent leaves; flowers unknown. Fruit crustaceous, narrow-ovate, $5.2-5.6 \mathrm{~cm}$ long, 1.0 $2.8 \mathrm{~cm}$ wide, with no distinct wing-like apical appendage, apex rounded, base inflated, evenly shaped. Fig. 7.

RECOGNITION. Most similar to Smythea lanceata with respect to the inflated glabrous fruit, widest near their base and borne in the axils of persistent leaves, but differs in the $5-7$ pairs of secondary veins, set closer to each other along the primary vein, with the veins midway along separated by c. a fifth of the total lamina length, and in the absence of conspicuous domatia.

DISTRIBUTION. Only known from Doi Phu Kha National Park in Nan Province, Thailand. Map 1.

HABITAT. Luang Prabang montane rain forest; alt. $1700 \mathrm{~m}$.

CONSERVATION StATUS. Data deficient (DD). IUCN Standards and Petitions Subcommittee Guidelines (2016) state that if data are so uncertain that both Critically Endangered (CR) and Least Concern (LC) are plausible categories, the DD category can be used for a taxon. The only specimen available was collected in 1995 and the species is known only from a single collection location in the Luang Prabang Range and thus meets the Bla criterion for Critically Endangered (CR) status. However, the species was found inside an IUCN Category II (National Park) area. Lack of collections and field observations of the species do not allow inference of decline or fluctuation in population size or EOO and AOO.

PHENOLOGY. Collected in fruit in August.

ETYMOLOGY. Smythea poomae is named in honour of botanist Rachun Pooma, based at the Bangkok Forest Herbarium, who has undertaken much botanical exploration throughout Thailand and collected the type specimen in 1995 .

NOTES. Smythea poomae is easily recognised by its inflated, wingless fruit with a rounded apex and secondary veins relatively close to each other along the primary vein. The only other species with an inflated fruit in the genus is $S$. lanceata but this is found mainly in coastal and mangrove habitats. In this region of Thailand adjacent to Indo-China (as applied to Cambodia, Laos and Vietnam and usually excluding Thailand), S. poomae is the only recorded taxon of Smythea from the Luang Prabang Range. Smythea oblongifolia is found in many parts of Thailand but differs in having leaves with a narrower angle of divergence of secondary veins and leafless panicles with fruit which are hairy and have a wing-like appendage. Smythea poilanei was collected in Laos in nearby Vientiane Prefecture but differs in having leaves with a rounded to broadly cuneate base, $2-4$ pairs of secondary veins and conspicuous domatia; in addition, the species are unlikely to be sympatric, as biogeographically, the floras of Nan and Vientiane are quite different, with the Vientiane flora more similar to that from the north-eastern Thai Provinces of Nong Khai and Bueng Kan (Middleton, pers. comm.).

11. Smythea velutina (Ridl.) S. P. Banerjee $\mathcal{E} P$. K. Mukh. (Banerjee \& Mukherjee 1969: 251). Ventilago velutina Ridl. (Ridley 1922: 467). Type: Malaysia, Peninsular Malaysia, Perak, s.a., Scortechini s.n. (lectotype, designated by Banerjee \& Mukherjee 1969: CAL; isolectotypes $\mathrm{E}$ !, $\mathrm{K}$ !).

DISTRIBUTION. Peninsular Malaysia (Federal Territory of Kuala Lumpur, Negeri Sembilan, Pahang, Perak, Selangor) and Thailand (Narathiwat, Pattani). Map 4. SPECIMENS EXAMINED. MALAYSIA. PENINSULAR MALAYSIA: FEDERAL TERRITORY OF KUALA LUMPUR, Lake Garden [3 $\left.8^{\prime} 45^{\prime \prime} \mathrm{N} 101^{\circ} 41^{\prime} 15^{\prime \prime E}\right]$, c. $200 \mathrm{ft}[50 \mathrm{~m}], 20$ May 1961, Kasim 1284 (K!); Kepong [3¹2'15"N 101 38'30"E], 12 Oct. 1929, Symington 20886 (K!, KEP!); NEGERI SEMBILAN, Pasoh Forest Reserve [ $3^{\circ} 2^{\prime} \mathrm{N}$ $102^{\circ} 20^{\prime} \mathrm{E}$ ], 80 - 120 m, 9 June 1996, Gardette et al. E.G. 1984 (A!, K!, KEP!); ibid., 6 May 1996, Gardette et al. E.G. 1785 (A!, K!, KEP!); ibid., 7 Feb. 1996, Gardette et al. E.G. 1523 (KEP!); Pasoh F.R. Flat Land, 24 July 1987, Kochummen FRI 26636 (K!, KEP!); PAHANG, Gorge of S. Tras, near Raub [ $\left.3^{\circ} 45^{\prime} \mathrm{N} 101^{\circ} 47^{\prime} \mathrm{E}\right], \pm 500 \mathrm{ft}$ [150 m], 12 Nov. 1929, Burkill 16802; PERAK, Piah FR, Kuala Kangsar [5 ${ }^{\circ}$ 'N $101^{\circ} 4$ 'E], 15 July 1967, Kochummen FRI 2456 (A!, K!, KEP!, L!); Keledang Saiong F. Res. [ $4^{\circ} 40^{\prime} \mathrm{N} 101^{\circ} \mathrm{E}$ ], 6 Feb. 1934, Tachin F.M.S. 33617; s.l., s.a., Scortechini 1405 (CAL!-image seen, K!, L!); SELANGOR, Ulu Sg. Batu recreation area. Km 6 Ulu Yam road. [3 ${ }^{\circ} 18^{\prime} 15^{\prime \prime} \mathrm{N}$ $101^{\circ} 41^{\prime} 45^{\prime \prime} \mathrm{E}$ ], 100 m, 3 June 1994, Zainudin 5087 (KEP!); Ulu Klang, forest reserve [ $3^{\circ} 11^{\prime} \mathrm{N} 101^{\circ} 48 ' \mathrm{E}$ ], 10 June 1971, Teo E⿱ $\mathcal{F}^{\circ}$ Pachiappan 402 (K!, L!). THAILAND. NARATIWHAT: Bala-hala, Sukhirin [5 56'30' N 101 41'45"E], 23 Aug. 1998, Puudjaa 499 (BKF!); Klong Iga Deng, Waeng [554'N 101 52 'E], 12 Aug. 1996, Puudjaa 303 (BKF!); PATTANI: Ban Rubi Toh Moh [6 $\left.34^{\prime} \mathrm{N} 101^{\circ} 33^{\prime} \mathrm{E}\right], 500 \mathrm{ft}[150 \mathrm{~m}], 17$ April 1931, Lakshnakara 668 (K!, L!, P!-image seen).

hABITAT. Malay Peninsula rain forests; alt. $50-150 \mathrm{~m}$. CONSERVATION STATUS. Near Threatened (NT). The taxon is very likely declining given the widespread destruction of much of its habitat, especially in the lowland rainforests of the Malay Peninsula (Loucks 2001), and its collection locations are fragmented. 


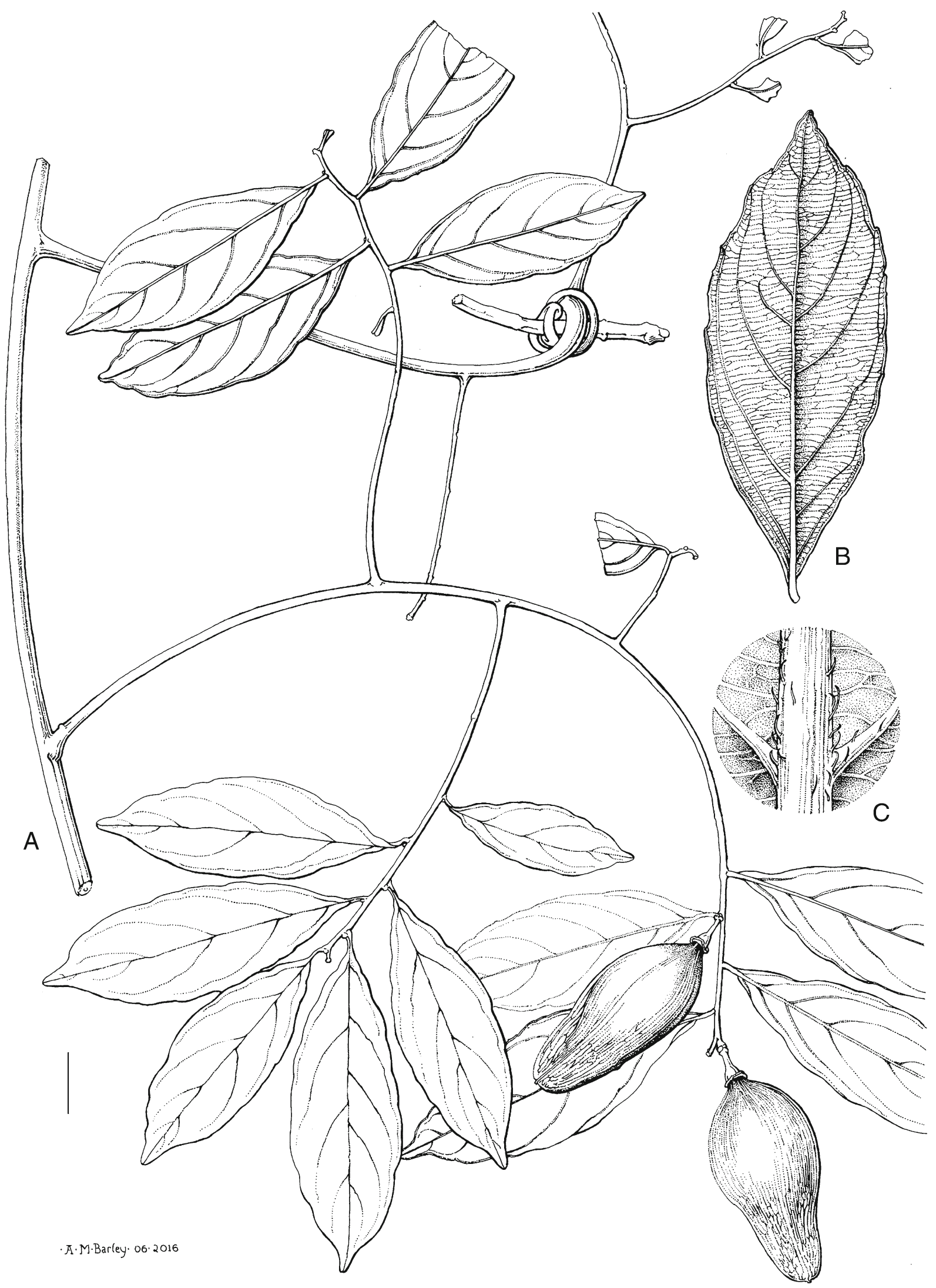

Fig. 7. Smythea poomae. A habit; B leaf, abaxial view; $C$ midrib, abaxial view. Scale bar: $A=1.5 \mathrm{~cm} ; B=1 \mathrm{~cm} ; C=0.1 \mathrm{~mm}$. All from POOMa 1112. DRAWN BY ANITA BARLEY. 
However, the taxon does not currently qualify as threatened, as it has an EOO greater than 30,000 $\mathrm{km}^{2}$ and has been collected recently in suitable habitats still remaining in the region such as Pasoh Forest Reserve.

PHENOLOGY. Collected in flower from April to June and Oct.; collected in fruit from April to Aug. and Nov.

NOTES. Smythea velutina is easily recognised as being the only known species in the genus with a completely hairy abaxial surface on mature leaves. The only other taxa of Smythea found in the Malay Peninsula are $S$. lanceata, $S$. macrocarpa and S. oblongifolia. Smythea velutina differs from S. lanceata in the hairy, elliptic to oblong wing-like fruit, the hairy abaxial leaf lamina and the more numerous and prominent secondary veins. Apart from the hairy abaxial leaf lamina and fruit, the overall morphology of $S$. velutina is very similar to that of $S$. macrocarpa. In addition to the hairy abaxial leaf surface, S. velutina differs from S. oblongifolia in the flower fascicles being located in the axils of persistent leaves and in the lateral veins ascending less acutely and not readily forming loops near the more finely serrated leaf margins.

Banerjee \& Mukherjee (1969) designated Scortechini s.n. (CAL n.v.) as the type specimen for Smythea velutina. The labels on Scortechini herbarium sheets of $S$. velutina neither specify a precise collection location nor a collection date, although some are numbered and others unnumbered. Scortechini s.n. (E!, K!), both specimens of $S$. velutina, presumably collected at the same location and date in Perak as the Calcutta type specimen, are considered here as isolectotypes (note: there is no confusion with Scortechini 2110 in CAL, which has Ventilago fruits and is a specimen of $V$. malaccensis collected from a completely different plant, see Doubtful and excluded names below). The specimens numbered Scortechini 1045 (CAL!-image seen, K!, L!) may or may not be additional duplicates.

\section{Doubtful and excluded names}

Smythea hollrungii K. Schum. ex Weberb. nom. nud.

This name is not recorded on IPNI, but is used in Banerjee \& Mukherjee (1970) as Smythea hollrungii Weberb. The name was first used by Weberbauer (1895: 400), however, without reference to a specimen or a place of publication, but with an illustration of the fruit and the distribution given as Kaiser Wilhelms Land. Schumann \& Hollrung (1889: 73) and Schumann \& Lauterbach (1901: 426), stated that only $S$. novo-guineensis Scheff., now placed as a synonym of the widespread S. lanceata, was in Kaiser Wilhelms Land, and mention no other Smythea names. The illustration provided in
Weberbauer's figure does not comply with Art. 38.7. of the code to replace a written description or diagnosis (McNeill et al. 2012). We can only assume that Schumann communicated with Weberbauer that he was going to describe a new species to honour Hollrung. Unfortunately, Weberbauer was not subsequently informed that the name would not be published because the material matched a previously described taxon; hence, Weberbauer was under the false impression that the species name was seemingly available and could be used.

Smythea macrocarpa Hemsl. var. pubescens King (1896: 382), pro parte. Type: Malaysia, Peninsular Malaysia, Perak, Scortechini 2110 (lectotype, designated by Banerjee \& Mukherjee 1969: CAL!-image seen) = Ventilago malaccensis Ridl.

The fruits on Scortechini 2110 are clearly of Ventilago, being conspicuous and globose rather than the laterally compressed seed chambers found in Smythea. The other characters, such as leaf size and shape etc., are all an excellent match for $V$. malaccensis.

Smythea macrophylla Lauterb. (Lauterbach 1922: 328). Type: Papua New Guinea [Kaiser-Wilhlemsland], 6 July 1908, Schlechter 17906 (NY!-image seen [NY00415072], WRSL!-image seen).

This is best placed within Ventilago papuana Merr. \& L. M. Perry, with broad symmetric leaves, no distinctive domatia, a "leafless inflorescence" and a pubescent disk. This species forms a complex together with $V$. borneensis Ridl., and perhaps also $V$. microcarpa K. Schum. and V. madraspatana sensu Gaertn. Note that the latter, V. madraspatana, was the first species of Ventilago published, based on Rumphius's Funis viminalis from Ambon, and is a good match for this type with broad leaves with entire margins, $6-8$ pairs of abaxially almost flat secondary veins, no domatia at secondary vein axils and flowers with hairy nectary disks. However, the name $V$. madraspatana Gaertn. was then erroneously, and extensively, used for a commonly collected species from India, and now refers to the Indian Ventilago rather than the Ambonese one.

Smythea nitida Merr. (Merrill 1925: 136). Type: Hainan: Five Finger Mountains, 6 May 1920, c. 1350 m., Chun 1465 (holotype UC!-image seen [UC242632]). = Ventilago leiocarpa Benth. var. leiocarpa.

A species from southern China through to Myanmar and Vietnam, now placed in Ventilago, e.g., 
Chen \& Schirarend (2007: 165), especially on account of the globose seed chamber.

Smythea velutina (Ridl.) S. P. Banerjee \& P. K. Mukh. var. kingiana S. P. Banerjee \& P. K. Mukh. (Banerjee \& Mukherjee 1969: 251). Type: Malaysia, Peninsular Malaysia, Perak, Larut, June 1885, King's Collector 7726 (holotype CAL).

The specimen of King's Collector 7726 cannot be traced at CAL (Bhattacharjee pers. comm.), and we are therefore unable to place this name with confidence, although it is probably best placed as a synonym of $S$. velutina (see following). The type cited by Banerjee \& Mukherjee (1969), is a syntype of Smythea macrocarpa Hemsl. var. pubescens King, and the other syntype, Scortechini2110, we can confidently assign to $V$. malaccensis (see above). When publishing this new variety, Banerjee \& Mukherjee (1969) did not cite all the syntypes of the name (thus there was no holotype), and the name is not superfluous (see Art. 52.2). Banerjee \& Mukherjee (1969) described S. velutina var. kingiana with chartaceous, villous, dull-brown, elliptic-oblong fruit with an oblong, abruptly mucronate apex. However, specimens such as Kochummen FRI 2456 and Gardette et al. E.G. 1984, which have both young and mature fruit on the same sheet, suggest that the authors may have been describing immature fruit of $S$. velutina s.str.

\section{Dubious specimens}

The following specimen resembles Smythea hirtella by its relatively long petioles and abaxially very densely hairy primary veins, but its flower fascicles are not in leafless racemes.

MALAYSIA. SARAWAK: $1^{\text {st }}$ Div., $30 \mathrm{~km}$ SW of Kuching, Sebuaran Bau, below 500 m, 14 Sept. 1958, Jacobs 5475 (L!).

The following collection resembles Smythea macrocarpa by its glabrous fruit borne in the axils of persistent leaves, but the leaves have almost flat secondary veins, a more grossly crenate margin and a longer relative petiole length.

MALAYSIA. PENINSULAR MALAYSIA: KELANTAN, Ulu Kelantan, 1962, UNESCO Limestone Expedition 1962 138 (BKF!, K!, L!).

The following sterile specimen is similar to Smythea oblongifolia by having leaves with a very short petiole, an asymmetric base, domatia in secondary vein axils and a narrow-acute secondary vein angle of divergence, but the leaves are shorter (to c. $5 \mathrm{~cm}$ long) and have less conspicuously prominent secondary veins than on other S. oblongifolia specimens.
THAILAND. YALA: Than To, c. 100 m, 19 Nov. 1968, Smitinand 10536 (BKF!).

\section{Acknowledgements}

The authors thank the curators of the following herbaria for sending their material on loan: A, BKF, E, GH, KEP and L; we thank the curators and Director, Botanical Survey of India and the curator of WRSL for providing type images, and especially Avishek Bhattacharjee for his help with the nomenclatural status of several names; the ERASMUS programme for financial support for the first author; the artists Lucy Smith and Anita Barley for their excellent illustrations; and to Yayasan Pecinta Budaya Bebali for assistance in the field in Indonesia. The comments and suggestions of two anonymous reviewers were extremely useful and we thank them for helping to improve the paper; we also thank Heather Lindon, Helen Hartley and the rest of the IPNI editorial team for nomenclatural advice; and David Middleton for useful information on the floristics of Thailand and Indo-China.

Open Access This article is distributed under the terms of the Creative Commons Attribution 4.0 International License (http://creativecommons.org/ licenses/by/4.0/), which permits unrestricted use, distribution, and reproduction in any medium, provided you give appropriate credit to the original author(s) and the source, provide a link to the Creative Commons license, and indicate if changes were made.

\section{Appendix 1: Alphabetical index to numbered collections examined}

Aet 198 (S. lanceata); Ah Mat C.F. 2481 (S. macrocarpa); Amin SAN 115220 (S. lanceata); Atjeh 281 (S. lanceata); Atkins et al. 518 (S. macrocarpa).

Backer 21001 (S. lanceata); van Balgooy et al. 5918 (S. beccarii); Beccari 4062 (S. lanceata); Beers's collectors BSIP 6792 (S. lanceata); Beers's collectors BSIP 7096 (S. lanceata); Berhaman et al. AB 86 (S. oblongifolia); Bermejos 264 (S. oblongifolia); Bhargava 4408 (S. lanceata); Bloembergen 4417 (S. oblongifolia); Blume 137i (S. oblongifolia); Bon 2274 (S. oblongifolia); Borges 3410 (S. lanceata); van Borssum Waalkes 777 (S. lanceata); van Borssum Waalkes 3231 (S. lanceata); Brass 3197 (S. lanceata); Burkill $\mathcal{E}$ Haniff 16802 (S. velutina).

Canfield 527 (S. lanceata); Collins 1723 (S. oblongifolia); Corner 31460 (S. lanceata); Curtis 2429 (S. lanceata); Curtis 2439 (S. lanceata); Curtis 2780 (S. macrocarpa); Cushing 460 (S. lanceata).

Demoulin E S Smeets 5672 (S. lanceata); Djamhari 388 (S. lanceata); Dupont 17 (S. lanceata).

Elmer 12921 (S. oblongifolia). 
Fedilis Eீ Sumbing SAN 91824 (S. hirtella); Fedilis $\mathcal{E}$ Sumbing SAN 91829 (S. oblongifolia); Fisher 7 (S. lanceata); Fosberg 26147 (S. lanceata); Fosberg 26395 (S. lanceata).

Gadoh anak Umbai K.L. 1043 (S. oblongifolia); Gadoh anak Umbai K.L. 2119 (S. macrocarpa); Gaerlan et al. PPI 2986 (S. lanceata); Gaerlan E Sagcal PPI 10154 (S. lanceata); Gafui $\mathcal{E}^{2}$ collectors BSIP 7536 (S. lanceata); Gardette et al. E.G. 1523 (S. velutina); Gardette et al. E.G. 1785 (S. velutina); Gardette et al. E.G. 1984 (S. velutina); Gaudichaud 111 (S. lanceata); Gillespie 4589 (S. lanceata); Goethebeur 3212 (S. lanceata); Goethebeur 3363 (S. lanceata); Gray E F Floyd N.G.F. 8010 (S. lanceata); Greenwood 264 (S. lanceata); Greenwood 264A (S. lanceata); Greenwood 264C (S. lanceata).

Haniff 9142 (S. macrocarpa); Harmand 300 (S. oblongifolia); Hartley T.G.H. 10,290 (S. lanceata); Hartley T.G.H. 11,075 (S. lanceata); Helfer 2026/1 (S. calpicarpa); Hellwig 435 (S. lanceata); Henderson 20171 (S. oblongifolia); Hennipman 5818 (S. beccarii); Heya et al. SAN 72488 (S. macrocarpa); Hollrung 93 (S. lanceata); Horne 376 (S. lanceata); Horne 502 (S. lanceata).

Idjan E Mochtar 398 (S. lanceata); Inimua BSIP 6541 (S. lanceata); Iserentant 9022 (S. lanceata).

Ja'amat bin Keling 39697 (S. macrocarpa); Jimpin SAN 139252 (S. macrocarpa); Joel et al. SAN 152284 (S. lanceata). Kanehira 2397 (S. lanceata); Kasim 1284 (S. velutina); Kerr 7320 (S. macrocarpa); Kerr 9827 (S. oblongifolia); Kerr 9876 (S. oblongifolia); Kerr 12427 (S. oblongifolia); Kerr 13824 (S. oblongifolia); Kerr 19838 (S. oblongifolia); Kiah 24342 (S. macrocarpa); King's Collector 2817 (S. macrocarpa); King's Collector 3154 (S. macrocarpa); King's Collector 3334 (S. macrocarpa); King's Collector 3472 (S. macrocarpa); King's Collector 3596 (S. macrocarpa); King's Collector 3628 (S. macrocarpa); Kochummen F.R.I. 2456 (S. velutina); Kochummen F.R.I. 26636 (S. velutina); Kornassi 979 (S. lanceata); Kornassi 1205 (S. lanceata); Koroivebau 13670 (S. lanceata); Kostermans 18583 (S. oblongifolia); Krispinus SAN 95986 (S. hirtella); Krispinus SAN 95994 (S. hirtella); Krispinus SAN 116699 (S. macrocarpa); Krispinus SAN 119608 (S. macrocarpa); Krispinus SAN 127611 (S. macrocarpa); Krispinus SAN 136138 (S. macrocarpa).

Lakshnakara 668 (S. velutina); Lamtoh SAN 68070 (S. lanceata); Larsen et al. 31011 (S. lanceata); Loher 5823 (S. oblongifolia); Lütjeharms 4699 (S. lanceata).

Madani E Prof Goh SAN 145373 (S. hirtella); Mail B.N.B. 1655 (S. oblongifolia); Mail B.N.B. 3648 (S. oblongifolia); Mantor SAN 130075 (S. macrocarpa); Mantor SAN 131530 (S. macrocarpa); Maradjo 404a (S. oblongifolia); Mauriasi E collectors BSIP 13620 (S. lanceata); Mauriasi E collectors BSIP 13790 (S. lanceata); Mauriasi E collectors BSIP 16574 (S. lanceata); Maxwell 02-777 (S. oblongifolia); Maxwell 81-64 (S. macrocarpa); Merrill 11626 (S. lanceata); Milne 289 (S. lanceata); Moi 136 (S. lanceata).
Narciso Jr 37293 (S. lanceata); Nedi 222 (S. oblongifolia); van Niel 4188 ( $S$. lanceata).

van Ooststroom E् Lütjeharms 11186 (S. lanceata).

Perrottet 9 (S. lanceata); Pierre 4045 (S. oblongifolia); Pleyte 821 (S. lanceata); Poilane 28085 (S. poilanei); Prawiroatmodjo E् Soewoko 1769 (S. beccarii); Puudjaa 303 (S. velutina); Puudjaa 499 (S. velutina).

Rachmat 807 (S. lanceata); Ramon 167 (S. lanceata); Ramos FB 27197 (S. oblongifolia) Ramos 39822 (S. oblongifolia); Ramos FB 76819 (S. oblongifolia); Ramos BS 80170 (S. batanensis); Ramos E Edaño FB 46648 (S. oblongifolia); Ridley 3592a (S. lanceata); Ridley 9151 (S. lanceata); Ridley 13349 (S. oblongifolia); Ridsdale 609 (S. bombaiensis); Robinson 1818 (S. lanceata); Rup Chand 6177 (S. oblongifolia).

Sayers N. G. F. 21704 (S. lanceata); Schmutz 3002 (S. oblongifolia); Schmutz 3356 (S. oblongifolia); Schram BW 10623 (S. lanceata); Scortechini 1405 (S. velutina); Seemann 79 (S. lanceata); Sinclair 10807 (S. lanceata); Sinclair 39006 (S. lanceata); van Slooten E Backer 35069 (S. lanceata); Smith 6628 (S. lanceata); Smith et al. 16822 (S. lanceata); Spare 931 (S. lanceata); Spare 37612 (S. macrocarpa); van Steenis 17851 (S. oblongifolia); Stone E Mahmud Sidek 12517 (S. macrocarpa); Stone E Streimann LAE 53585 (S. lanceata); Stone et al. PPI 12111 (S. lanceata); Strugnell 11147 (S. macrocarpa); Sudin 9815 (S. lanceata); Sulit 35801 (S. oblongifolia); Sumbing SAN 127672 (S. macrocarpa); Sundaling SAN 93192 (S. macrocarpa); Sundaling et al. SAN 109264 (S. macrocarpa); Symington 20886 (S. velutina).

Tachin F.M.S. 33617 (S. velutina); Tagane et al. T 1484 (S. oblongifolia); Talbot de Malahide 88 (S. poilanei); Teijsmann 779 (S. lanceata); Teijsmann 2977 (S. lanceata); Teijsmann 7579 (S. lanceata); Teijsmann 7779 (S. lanceata); Teo E Pachiappan 402 (S. velutina); Teruya 360 (S. lanceata); Tothill 74 (S. lanceata); Tothill 479 (S. lanceata); Tothill 7479 (S. lanceata); Toxopeus 628 (S. lanceata).

Ubaldus et al. SAN 149661 (S. lanceata).

Verdcourt Eं Katik 4965 (S. lanceata); Verheijen 3242 (S. oblongifolia); Verheijen 3945 (S. oblongifolia); Vidal 198 (S. oblongifolia); Vidal 1117 (S. lanceata); Villamil 21408 (S. oblongifolia); Vogel 4258 (S. lanceata).

Waterhouse 346 (S. lanceata); Weinland 279 (S. lanceata); Whitmore BSIP 4022 (S. lanceata); Whitmore's collectors BSIP 2925 (S. lanceata); Wilde Eे Wilde-Duyfjes 13903 (S. macrocarpa); Wilde $\mathcal{E}$ Wilde-Duyfjes 15887 (S. macrocarpa); Wray 36 (S. macrocarpa); Wray 2211 (S. macrocarpa).

Zainudin et al. 3840 (S. oblongifolia); Zainudin et al. 5087 (S. velutina).

\section{References}

Bachman, S., Moat, J., Hill, A., de la Torre, J. \& Scott, B. (2011). Supporting Red List threat assessments with GeoCAT: Geospatial Conservation Assessment Tool. ZooKeys 150: 117 - 126. 
Baker, J. G. (1877). Flora of Mauritius and the Seychelles. L. Reeve \& Co, London.

Banerjee, S. P. \& Mukherjee, P. K. (1969). Studies in the Rhamnaceae. I. Smythea velutina (Ridl.) S. P. Ban. and P. K. Mukh. comb. nov. and description of a new variety under it. Bull. Bot. Surv. India 10: 251 - 253.

\&

(1970). Studies in the Rhamnaceae, III.

A Taxonomic Revision of Indian Ventilagineae. Indian Forester 96: 203 - 217.

Beentje, H. (2010). The Kew Plant Glossary: An Illustrated Dictionary of Plant Terms. Royal Botanic Gardens, Kew.

Blume, C. L. von. (1826). Bijdragen tot de Flora van Nederlandsch Indië, vol. 17: 1144. Ter Lands Drukkerij, Batavia.

Cahen, D. \& Utteridge, T. M. A. (2017). Three new species of Ventilago (Rhamnaceae) from South-East Asia. Phytotaxa 307: 171 - 182.

Chen, Y.-L. \& Schirarend, C. (2007). Rhamnaceae. In: Z.-Y. Wu, P. H. Raven \& D.-Y. Hong (eds), Flora of China 12: 115 - 168. Science Press, Beijing, and Missouri Botanical Garden Press, St. Louis.

Dalzell, N. A. (1851). Contributions to the Botany of Western India. Hooker's J. Bot. Kew Gard. Misc. 3: 33 39.

Gray, A. (1862). Plantae Vitiensis Seemannianae. Remarks on the Plants collected in the Vitian or Fijian Islands by Dr. Berthold Seemann. Bomplandia 10: 34 - 37.

Guppy, H. B. (1906). Observations of a naturalist in the Pacific between 1896 and 1899. Vol. 2. Plant Dispersal. Macmillan, London.

Hemsley, W. B. (1887). Smythea macrocarpa Hemsl. In: J. D. Hooker (ed.), Hooker's Icon. Pl. 16: t. 1558.

(1916). Flora of Seychelles and Aldabra: new phanerogamia, chiefly of the Percy Sladen Trust Expedition, with some emendations in synonymy. J. Bot. 54, Suppl. II: $1-24$.

Hickey, L. J. (1979). A revised classification of the architecture of dicotyledonous leaves. In: C. R. Metcalfe \& L. Chalk (eds), Anatomy of the dicotyledons. Second Edition. Volume 1. Systematic anatomy of the leaf and stem, pp. 25 - 39. Oxford Science Publications, Oxford.

Hooker, J. D. (1862). Rhamnaceae. In: G. Bentham \& J. D. Hooker (eds), Genera Plantarum, vol. 1: 371 386. Reeve \& Co., London.

IUCN (2012). IUCN Red List Categories and Criteria: Version 3.1, Second edition. IUCN, Gland and Cambridge. \& UNEP-WCMC (2016). The World Database on Protected Areas (WDPA). Cambridge. Available from: www.protectedplanet.net (accessed: 31 March 2016).

Standards and Petitions Subcommittee (2016).

Guidelines for Using the IUCN Red List Categories and Criteria. Version 12. Prepared by the Standards and Petitions Subcommittee. Available from: http:// www.iucnredlist.org/documents / RedListGui delines.pdf (accessed: 31 March 2016).
King, G. (1896). Materials for a Flora of the Malayan Peninsula. J. Asiat. Soc. Bengal Pt. 2. Nat. Hist. 65: 339 - 516.

Kurz, W. S. (1872). New Burmese Plants. J. Asiat. Soc. Bengal, Pt. 2. Nat. Hist. 41: 291 - 318.

Lauterbach, C. (1922). Die Rhamnaceen Papuasiens. Bot. Jahrb. Syst. 57: 326 - 340.

Loucks, C. (2001). Southeastern Asia: Indonesia and Malaysia. Available from: http://www.worldwildlife.org/ ecoregions/im0102 (accessed: 31 March 2016).

McNeill, J., Barrie, F. R., Buck, W. R., Demoulin, V., Greuter, W., Hawksworth, D. L., Herendeen, P., Knapp, S., Marhold, K., Prado, J., Prud'homme Van Reine, W. F., Smith, G. F., Wiersama, J. H. \& Turland, N. J. (eds) (2012). International Code of Nomenclature for algae, fungi, and plants (Melbourne Code). Regnum Veg. 154. Koeltz Scientific Books.

Medan, D. \& Schirarend, C. (2004). Rhamnaceae. In: K. Kubitzki (ed.), The Families and Genera of Vascular Plants, Vol. 6: Celastrales, Oxalidales, Rosales, Cornales, Ericales, pp. 320 - 338. Springer-Verlag, Berlin Heidelberg.

Merrill, E. D. (1909). New or Noteworthy Philippine Plants. VII. Philipp. J. Sci., C 4: 247 - 330.

(1916). Reliquiae Robinsonianae. Philipp. J. Sci., C 11: $243-319$.

(1925). Additions to our knowledge of the flora of Hainan. J. Arnold. Arbor. 6: 129 - 140.

Miquel, F. A. W. (1861). Flora van Nederlandsch Indie, Eerste Bijuoegsel. Van der Post, Amsterdam and van der Post Jr., Utrecht.

Morrison, J. (2001). Indonesia: Island of Sulawesi. Available from: http://www.worldwildlife.org/ ecoregions/aa0123 (accessed: 31 March 2016).

Newman, M., Ketphanh, S., Svengsuksa, B., Thomas, P., Sengdala, K., Lamxay, V. \& Armstrong, K. (2007). Checklist of the vascular plants of Lao PDR. Royal Botanic Garden Edinburgh, Edinburgh.

Olson, D. M., Dinerstein, E., Wikramanayake, E. D., Burgess, N. D., Powell, G. V. N., Underwood, E. C., D'amico, J. A., Itoua, I., Strand, H. E., Morrison, J. C., Loucks, C. J., Allnutt, T. F., Ricketts, T. H., Kura, Y., Lamoreux, J. F., Wettengel, W. W., Hedao, P. \& Kassem, K. R. (2001). Terrestrial Ecoregions of the World: A New Map of Life on Earth. BioScience 51: 933 - 938.

Pierre, L. (1894). Rhamnacées. Flore Forestière Cochinchine, Vol. 3: t. 313 - 316. O. Doin, Paris.

Rawat, G. S., Desai, A., Somanathan, H. \& Wikramanayake, E. D. (2001). Southern Asia: Southern India. Available from: http://www.worldwildlife.org/ ecoregions/im0150 (accessed: 31 March 2016).

Richardson, J. E., Fay, M. F., Cronk, Q. C. B., Bowman, D. \& Chase, M. W. (2000). A Phylogenetic Analysis of Rhamnaceae using rbcL and trnL-F Plastid DNA Sequences. Amer. J. Bot. 87: 1309 - 1324.

Ridley, H. N. (1922). Flora of the Malay Peninsula, Vol. 1: 461 - 468. L. Reeve, London. 
(1924). New Malayan Plants. J. Bot. 62: 294 - 301. (1930). The Dispersal of Plants Throughout the World. L. Reeve, London.

Scheffer, R. H. C. C. (1876). Enumeration des plantes de la Nouvelle-Guinée, avec déscription des espèces nouvelles. Ann. Jard. Bot. Buitenzorg. 1: 1 - 60.

Schneider, C. K. (1916). Rhamnaceae. In: C. S. Sargent (ed.), Plantae Wilsonianae, An Enumeration of the Woody Plants Collected in Western China for the Arnold Arboretum of Harvard University. Vol. 2: 209 - 253. The University Press, Cambridge.

Schumann, K. \& Hollrung, M. (1889). Die Flora von Kaiser Wilhelms Land. Asher \& Co., Berlin, Kommissions-Verlag.

\& Lauterbach, K. (1901). Die Flora der Deutschen Schutzgebiete in der Südsee. Verlag von Gebrüder Borntraeger, Leipzig.

Seemann, B. (1861). Plantae Vitienses. Bomplandia 9: 253 262.

(1862). Smythea Pacifica. Bonplandia 10: 69 - 70.

Srikosmatara, S., Round, P. D. \& Wikramanayake, E. D. (2001). Southerneastern Asia: Southern Thailand. Available from: http://www.worldwildlife.org/ ecoregions/im0108 (accessed: 31 March 2016).

Stafleu, F. A. \& Cowan, R. S. (1986). Taxonomic literature. A selective guide to botanical publications and collections with dates, commentaries and types. Volume VI: Sti - Vuy, Second edition. Bohn, Scheltema and Holkema, Utrecht and Antwerp.

Suessenguth, K. (1953). Rhamnaceae. In: A. Engler \& K. Prantl (eds), Die Natürlichen Pflanzenfamilien Zweite Auflage Band 20d: 1 - 173. Duncker and Humbolt, Berlin.

Summerhayes, V. S. (1928). New Plants from the Seychelles. Bull. Misc. Inform., Kew 1928: 389.
(1931). An enumeration of the angiosperms of the Seychelles Archipelago. Trans. Linn. Soc. London 19(2): 261 - 299.

Theobald, W. L., Krahulik, J. L. \& Rollins, R. C. (1979). Trichome description and classification. In: C. R. Metcalfe \& L. Chalk (eds), Anatomy of the dicotyledons. Second Edition. Vol. 1. Systematic anatomy of the leaf and stem, pp. 40 - 53. Oxford Science Publications, Oxford.

Tulasne, L. R. (1857). Florae Madagascariensis Rhamneae. Ann. Sci. Nat., Bot. Ser. 4, 8: 120 - 126.

Vidal, S. (1886). Revision de plantas vasculares Filipinas. M. Perez, Manila.

Weberbauer, A. (1895). Rhamnaceae. In: A. Engler \& K. Prantl (eds), Die Natürlichen Pflanzenfamilien III. Teil 5. Abteilung, pp. 393 - 427. W. Engelmann, Leipzig.

Wieczorek, C. \& Wieczorek J. (2015). Georeferencing Calculator. Version 20151221. Museum of Vertebrate Zoology, University of California, Berkeley. Available from: http://manisnet.org/gci2.html. (accessed: 29 March 2016).

Wieczorek, J., Guo, Q. \& Hijmans, R. (2004). The point-radius method for georeferencing locality descriptions and calculating associated uncertainty. Int. J. Geogr. Inform. Sci. 18(8): 745 - 767.

Wikramanayake E. D., Boonratana, R., Rundel, P. \& Aggimarangsee, N. (2001). Southeastern Asia: Thailand, Cambodia, Laos, and Vietnam. Available from: http://www.worldwildlife.org/ecoregions/ im0202 (accessed: 31 March 2016).

Wilkinson, H. P. (1979). The Plant Surface (Mainly Leaf) Part IV Domatia. In: C. R. Metcalfe \& L. Chalk (eds), Anatomy of the dicotyledons. Second Edition. Volume 1. Systematic anatomy of the leaf and stem, pp. 132 - 140. Oxford Science Publications, Oxford. 